\title{
Gastroprotective effects of hydroethanolic root extract of Arrabidaea brachypoda: Evidences of cytoprotection and isolation of unusual glycosylated polyphenols
}

\author{
Claudia Quintino da Rocha ${ }^{\text {a, b }}$, Felipe Meira de-Faria ${ }^{\text {c, d }}$, Laurence Marcourt ${ }^{\text {b }}$, \\ Samad Nejad Ebrahimi e, Bruna Tiemi Kitano ${ }^{\mathrm{d}}$, Amanda Franceschini Ghilardi ${ }^{\mathrm{d}}$, \\ Anderson Luiz Ferreira ${ }^{\mathrm{d}, \mathrm{f}}$, Ana Cristina Alves de Almeida ${ }^{\mathrm{d}}$, Ricardo José Dunder ${ }^{\mathrm{c}}$, \\ Alba Regina Monteiro Souza-Brito ${ }^{\mathrm{c}, \mathrm{d}}$, Matthias Hamburger ${ }^{\mathrm{g}}$, Wagner Vilegas ${ }^{\mathrm{a},{ }^{* *} \text {, }}$

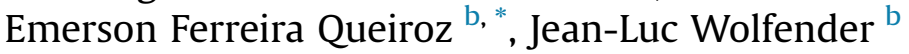 \\ a Institute of Biosciences, Coastal Campus of São Vicente, Universidade Estadual Paulista-UNESP, 11330-900, São Vicente, SP, Brazil \\ b School of Pharmaceutical Sciences, University of Geneva, University of Lausanne, Centre Medical Universitaire-CMU, Rue Michel-Servet 1, CH-1211, Geneva \\ 4, Switzerland \\ ${ }^{c}$ Department of Pharmacology, Faculty of Medical Sciences, State University of Campinas-UNICAMP, 13083-970, Campinas, SP, Brazil \\ d Department of Structural and Functional Biology, Institute of Biology, State University of Campinas-UNICAMP, 13083-970, Campinas, SP, Brazil \\ e Department of Phytochemistry, Medicinal Plants and Drugs Research Institute, Shahid Beheshti University, G. C., Evin, Tehran, Iran \\ ${ }^{\mathrm{f}}$ Nucleus of Biological Sciences, Institute of Biotechnology, Federal University of Goias, 75704-020, Catalão, GO, Brazil \\ ${ }^{g}$ Division of Pharmaceutical Biology, Department of Pharmaceutical Sciences, University of Basel, Klingelbergstrasse 50, CH-4056 Basel, Switzerland
}

\section{A R T I C L E I N F O}

\section{Article history:}

Received 13 July 2016

Received in revised form

23 November 2016

Accepted 2 December 2016

Available online 21 December 2016

\section{Keywords:}

Arrabidaea brachypoda

Bignoniaceae

Gastric ulcer

Gastroprotective effect

In vivo assays

Glycosylated dimeric flavonoids

\begin{abstract}
A B S T R A C T
The hydroethanolic root extract of Arrabidaea brachypoda, from Bignoniaceae family, a Brazilian medicinal plant, demonstrated significant in vivo gastroprotective effects using different in vivo assays. The activity was evaluated in several models of experimental gastric ulcer in rats (absolute ethanol, glutathione depletion, nitric oxide depletion, non-steroidal anti-inflammatory drugs, pylorus ligation and acetic acid). Using $300 \mathrm{mg} / \mathrm{kg}$ (p.o.) the extract significantly reduced gastric injury in all models. In depth phytochemical investigation of this extract led to the isolation of two previously undescribed phenylethanoid glycosides derivatives and seven unusual glycosylated dimeric flavonoids. The structures were elucidated using UV, NMR and HRMS analysis. Absolute configuration of the dimeric flavonoids was performed by electronic circular dichroism (ECD) spectroscopy.
\end{abstract}

๑) 2016 Elsevier Ltd. All rights reserved.

\section{Introduction}

Gastric ulcer development is thought to result from an imbalance between mucosal defensive mechanisms, including mucus, bicarbonate, prostaglandins (PGs) and maintenance of the mucosal blood flow. In addition, damaging factors such as acid and pepsin in the luminal surface of the gastric mucosa play also a role (Laine

\footnotetext{
* Corresponding author.

** Corresponding author.

E-mail addresses: vilegasw@gmail.com (W. Vilegas), emerson.ferreira@unige.ch (E.F. Queiroz).
}

et al., 2008).

It is also known that multiple factors can trigger gastric damage including, but not restricted to, Helicobacter pylori infection, ethanol consumption, the use of non-steroidal anti-inflammatory drugs (NSAID), dietary habits and stress (Malfertheiner et al., 2009; Yuan et al., 2006).

Despite the fact that conventional treatments like acid suppressant drugs (e.g. cimetidine and lansoprazole) and antibiotic for eradication of $H$. pylori or NSAID withdrawal usually improve gastric ulcer recovery, these treatments are insufficient for complete ulcer healing thus intimately linked to ulcer recurrence (Quan and Talley, 2002).

There are other targets than acid secretion where cytoprotection 
still takes important place on gastric ulcer therapy. Increased mucus production could be assumed as a central factor in ulcer healing by protecting the damaged tissue from several aggressors (Szabo, 2014). In fact, mucus secretion is an obvious contributor in improving epithelial recovery after injury through formation of a mucoid layer beneath initialising re-epithelisation (Arakawa et al., 2012).

In the light of the reported failure of current treatments for gastric ulcer (Malfertheiner et al., 2009; Tarnawski et al., 1990), natural extracts and their pure constituents emerge as highly effective in anti-ulcer treatment, possessing a gastroprotective action and being gentle on the body's systems (Farzaei et al., 2015; Kangwan et al., 2014).

The family Bignoniaceae encompasses 120 genera and approximately 800 species of plants that are distributed mostly in tropical and subtropical regions (Pauletti et al., 2003). The genus Arrabidaea belongs to the tribe Bignonieae and contains approximately 70 species that occur from Mexico to Argentina. This genus is a large and morphologically diverse clade of Neotropical lianas (Lohmann, 2006). Previous phytochemical studies have shown plants in this genus to produce C-glucosylxanthones, phenylpropanoids, flavonoids (including anthocyanidins), allantoin derivatives, and triterpenes (Gonzalez et al., 2000; Martin et al., 2008; Pauletti et al., 2003). In traditional medicine, species from the genus Arrabidaea are used for different therapeutic purposes and have astringent, anti-inflammatory, antimicrobial, and antitumor properties (Leite et al., 2006; Martin et al., 2008; Pauletti et al., 2003).

In Brazil, Arrabidaea brachypoda Bureau is commonly known as "cervejinha do campo" and is native to the "cerrado" ecosystem. Its traditional uses include the treatment of kidney stones and painful joints (arthritis), while it has also demonstrated significant in vivo anti-inflammatory activity in animal models (da Rocha et al., 2011).

Recently a random screening revealed that the dichloromethane extract of $A$. brachypoda presented significant in vitro anti-Trypanosoma cruzi activities. Bio-guided activity fractionation was performed and afforded unusual dimeric flavonoids possessing strong in vitro and in vivo anti-T. cruzi activities (da Rocha et al., 2014).

The purpose of the present study was to evaluate the gastroprotective effects of the hydroethanolic root extract of A. brachypoda (HEAb) in several induced-gastric ulcer models. An in depth phytochemical investigation of the active extract is also performed allowing to the isolation of nine previously undescribed natural products.

\section{Results and discussion}

\subsection{Investigation of the gastroprotective activities using in vivo models}

\subsubsection{Effect of oral pre-treatment with HEAb on rats submitted to ethanol-induced gastric lesions}

The hydroethanolic root extract of $A$. brachypoda (HEAb) was submitted to a series of in vivo assays in order to investigate its gastroprotective activities. Firstly the ability of HEAb in protecting the gastric mucosa of rats from injuries caused by oral administration of absolute ethanol was evaluated (Robert et al., 1979). Indeed ethanol is known to cause deterioration of gastric mucosa by increasing leukocyte infiltration, damaged mucosal blood flow and mucosal cell injury associated with overproduction of free radicals (de-Faria et al., 2012b) which can lead to cell death by cytotoxic effects and damage the tissues (Rahim et al., 2014). Doses from 10 to $300 \mathrm{mg} / \mathrm{kg}$ of HEAb were employed. The oral pretreatment with HEAb, 100 and $300 \mathrm{mg} / \mathrm{kg}$, decreased the gastric injury in $39 \%\left(p<0.05^{*}\right)$ and $51 \%\left(p<0.01^{* *}\right)$ respectively, the control lansoprazole presented $78 \%$ of inhibition, as shown in
Table 1.

2.1.2. Effect of the HEAb oral pre-treatment on rats injected with NEM and L-NAME submitted to ethanol-induced gastric lesions

After demonstrating the gastroprotective activity of HEAb and the dose capable of producing the maximum effect on the ethanolinduced gastric ulcer model $(300 \mathrm{mg} / \mathrm{kg}$ ), the possible mechanisms of action involved in HEAb gastroprotection were investigated in particular in relation with the involvement of sulfhydryls (SHs) and nitric oxide (NO). Indeed these major endogenous compounds protect cells in the stomach from both, free radical production and reduced blood flow, respectively (Matsuda et al., 1999).

Glutathione (GSH) and other SHs are the most widely distributed intracellular and extracellular protective agents in the organism, and have been implicated in the protection against chemically induced lesions such as the ethanol-induced gastric ulcer (Shaw et al., 1990). GSH protects the cell from free-radical induced damages by either protecting cells from lipid peroxidation or by protecting sulfhydryl groups from becoming irreversibly oxidized after oxidant injury, such as ethanol instillation (Szabo et al., 1992). On the other side NO regulates the gastric mucosa blood flow and gastric mucus secretion by increasing prostaglandin synthesis (Matsuda et al., 1999).

In order to check the participation of $\mathrm{SH}$ and NO in the gastroprotection promoted by HEAb, the ethanol-induced gastric injury model was employed using rats pre-treated with $\mathrm{N}$-ethylmaleimide (NEM), a GSH-blocker agent, or $\mathrm{N}^{\omega}$-Nitro-L-arginine methyl ester hydrochloride (L-NAME) a NO synthase inhibitor (Matsuda et al., 1999). The data obtained suggest that neither GSH nor NO are involved in the HEAb gastroprotection, once the administration of NEM or L-NAME does not lead to loss of HEAb (300 mg/kg) activity, as shown in Table 2 and Table 3 respectively. These data suggests that HEAb exerts its gastroprotection through different mechanisms than those evaluated.

\subsubsection{Effect of the HEAb oral pre-treatment on rats submitted to indomethacin-induced gastric lesions}

One of most relevant causes of peptic ulcer is the intake of NSAIDs which is very well known for inhibiting cyclooxygenase (COX) activities (Betton, 2013). Two isoforms of COX, namely a constitutive isoform, COX-1, and an inducible isoform, COX-2, have been proposed (Vane et al., 1998). It has been established that prostaglandins (PGs) derived from COX-1 contribute to the maintenance of gastric integrity, while elevated levels of PGs produced by COX-2 produce deleterious local and systemic effects such as an increase in vascular constriction and permeability, pain and fever associated with inflammation (Kwiecien et al., 2015). COX-2derived PGs have also demonstrated to have beneficial effects of to the gastrointestinal mucosa (Wallace and Devchand, 2005). In order to verify the effects of the impairment of COX (1 and 2) activities on HEAb gastroprotection, the effects of oral HEAb

Table 1

Effect of oral pre-treatment with HEAb $(10-300 \mathrm{mg} / \mathrm{kg})$ on rats submitted to ethanol-induced gastric lesions.

\begin{tabular}{lllll}
\hline Group & Dose $(\mathrm{mg} / \mathrm{kg})$ & $n$ & ULA $\left(\mathrm{mm}^{2}\right)$ & Inhibition $(\%)$ \\
\hline Control & - & 6 & $176.8 \pm 16.2$ & - \\
Lanzoprazole & 60 & 6 & $38.4 \pm 10.3^{* * *}$ & 78.2 \\
HEAb & 10 & 6 & $149.6 \pm 16.7$ & 15.3 \\
& 30 & 7 & $131.3 \pm 15.1$ & 25.7 \\
& 100 & 7 & $107.3 \pm 12.7^{* *}$ & 39.3 \\
& 300 & 6 & $86.6 \pm 9.5^{* * *}$ & 51.0 \\
\hline
\end{tabular}

Data $(n=6-7)$ are presented as mean values + s.e.m., using one-way ANOVA followed by Dunnett's post-test. Asterisks represent the level of statistical significance where ${ }^{* *} p<0.01$ and ${ }^{* * *} p<0.001$ compared to control group. 
administration in NSAID-induced gastric ulcer were investigated. The animals were pre-treated with HEAb (p.o.), and/or controls and 30 min later animal were treated with indomethacin (s.c., $40 \mathrm{mg}$ / $\mathrm{kg}$, a potent inhibitor of COX-1 and COX-2 (Wallace et al., 2000).

The results presented in Table 4 show that HEAb pre-treatment has protected (inhibition of $70 \%, p<0.01^{* *}$ ) the gastric mucosa against the insult caused by NSAID administration while the reference compound carbenoxolone presented $40 \%$ of inhibition. This finding indicates that HEAb may act on the PG (such as $\mathrm{PGE}_{2}$ ) pathway; carbenoxolone is known to increase the gastric mucous releasing (Kauffman, 1981) by inhibiting 15-PGDH activity, which catalyses the first step in PG deactivation (Peskar, 1980).

The protective mechanisms of gastric mucosa involve multiple factors, especially NO and PG production, which regulates blood flow, gastric acid secretion, bicarbonate and mucous formation (Laine et al., 2008). In the present study it was demonstrated that HEAb activity does not depend on NO functions (Table 3), but possibly on PG release and mucous formation based on the NSAID assay shown in Table 4. HEAb has protected the gastric mucosa against the effects caused by the inhibition of COX enzymes. This could be related to a specific action of HEAb constituents on the PG pathway. Here it has been excluded the NO participation and also, a direct effect of indomethacin upon epithelial gastric cells by administering it sub-cutaneously (Whittle, 1975).

\subsubsection{Effect of the HEAb oral pre-treatment on gastric mucus} adhered to gastric mucosal wall in rats

Based on these results it has been hypothesized that HEAb could be protecting gastric mucosa from injury by increasing mucous production and/or diminishing gastric acid secretions. To address these issues the model of pylorus ligation was employed, in which, rats are submitted to a pylorus ligation surgery inhibiting the gastric emptying, allowing to access the gastric content after a determined period of pylorus ligation, usually, four hours (Shay et al., 1945). To determine whether or not HEAb induces gastric mucous formation the animals are pre-treated with HEAb (p.o., $300 \mathrm{mg} / \mathrm{kg}$ ) and then, proceed to the experimental model - see experimental section (Corne et al., 1974). The data obtained show that HEAb pre-treatment has increased the gastric mucous adhered to gastric mucosa, as seen in Table 5. This result is in agreement with the data presenting the possible involvement of PGs in the HEAb activity (Table 4) and suggests that our hypothesis is, at least in part, right. HEAb may thus protects the gastric mucosa in a cytoprotective manner.

\subsubsection{Effect of the HEAb intra-duodenal treatment on gastric} secretion in rats submitted to pylorus ligation

In order to test the second part the hypothesis raised from the

Table 2

Effect of the HEAb (300 mg/kg) oral pre-treatment on rats injected with NEM (s.c. $10 \mathrm{mg} / \mathrm{kg}$ ) and submitted to ethanol-induced gastric lesions.

\begin{tabular}{lllll}
\hline Groups & Dose $(\mathrm{mg} / \mathrm{kg})$ & $n$ & ULA $\left(\mathrm{mm}^{2}\right)$ & Inhibition $(\%)$ \\
\hline Saline-injected rats & & & & \\
$\quad$ Control & - & 5 & $123.0 \pm 17.4$ & - \\
$\quad$ Carbenoxolone & 100 & 5 & $18.5 \pm 5.4^{* *}$ & 84.9 \\
HEAb & 300 & 5 & $45.0 \pm 6.5^{*}$ & 63.4 \\
NEM-injected rats & & & & \\
$\quad$ Control & - & 5 & $233.5 \pm 15.5$ & - \\
$\quad$ Carbenoxolone & 100 & 5 & $101.9 \pm 27.8^{* * *}$ & 56.3 \\
HEAb & 300 & 5 & $108.2 \pm 19.8^{* * *}$ & 53.6 \\
\hline
\end{tabular}

Data $(n=5)$ are presented as mean values \pm s.e.m., using one-way ANOVA followed by Tukey's post-test. Asterisks represent the level of statistical significance where ${ }^{*} p<0.05,{ }^{* *} p<0.01$ and ${ }^{* * *} p<0.001$ compared with their appropriate control group.
Table 3

Effect of the HEAb $(300 \mathrm{mg} / \mathrm{kg}$ ) oral pre-treatment on rats injected with L-NAME (i.p., $70 \mathrm{mg} / \mathrm{kg}$ ) submitted to ethanol-induced gastric lesions.

\begin{tabular}{lllll}
\hline Groups & Dose $(\mathrm{mg} / \mathrm{kg})$ & $n$ & ULA $\left(\mathrm{mm}^{2}\right)$ & Inhibition $(\%)$ \\
\hline Saline-injected rats & & & & \\
$\quad$ Control & - & 5 & $110.6 \pm 15.8$ & - \\
$\quad$ Carbenoxolone & 100 & 5 & $15.3 \pm 3.3^{* * *}$ & 86.1 \\
HEAb & 300 & 5 & $37.1 \pm 10.2^{* *}$ & 66.4 \\
L-NAME-injected rats & - & & & \\
$\quad$ Control & 100 & 6 & $187.3 \pm 17.7$ & - \\
$\quad$ Carbenoxolone & 300 & 5 & $22.1 \pm 9.3^{* * *}$ & 88.2 \\
HEAb & $30.1 \pm 10.5^{* * *}$ & 81.8 \\
\hline
\end{tabular}

Data $(n=5-6)$ are presented as mean values \pm s.e.m., using one-way ANOVA followed by Tukey's post-test. Asterisks represent the level of statistical significance where $^{* *} p<0.01$ and ${ }^{* * *} p<0.001$ compared with their appropriate control group.

Table 4

Effect of the HEAb (300 $\mathrm{mg} / \mathrm{kg}$ ) oral pre-treatment on rats submitted to indomethacin-induced gastric lesions (s.c., $30 \mathrm{mg} / \mathrm{kg}$ ).

\begin{tabular}{lllll}
\hline Groups & Dose $(\mathrm{mg} / \mathrm{kg})$ & $n$ & ULA $\left(\mathrm{mm}^{2}\right)$ & Inhibition $(\%)$ \\
\hline Control & - & 5 & $7.2 \pm 0.9$ & - \\
Carbenoxolone & 100 & 5 & $4.3 \pm 0.3^{*}$ & 40.2 \\
HEAb & 300 & 5 & $2.2 \pm 0.3^{* * *}$ & 69.4 \\
\hline
\end{tabular}

Data $(n=5-6)$ are presented as mean values \pm s.e.m., using one-way ANOVA followed by Dunnett's post-test. Asterisks represent the level of statistical significance where ${ }^{*} p<0.05$ and ${ }^{* * *} p<0.001$ compared to control group.

data of Table 4, the pylorus ligation model was employed. Anesthetized animals were submitted to surgical procedure to achieve pylorus ligation and after that the treatments (vehicle, cimetidine and HEAb) were intra-duodenally given and then the open regions were sewn. After four hours the animals were sacrificed and the stomachs collected for evaluation. It was observed that HEAb increased the $\mathrm{pH}$ of the gastric acid secretion (Table 6), but no effect was observed in the volume of gastric secretion. Cimetidine decreased the volume of acid secretion in $47 \%\left(p<0.01^{* *}\right)$ and increased the $\mathrm{pH}\left(p<0.01^{* * *}\right)$. The intra-duodenal treatment allows the experimenter to exclude the possibility of physical or direct effect of the tested drug. Thus, the results demonstrate that systemically given HEAb lead to diminished secretion of hydrogen ion into lumen and consequently increasing the $\mathrm{pH}$. This effect is in agreement with the data from gastric mucous formation, considering an allegedly effect on PGs, then, HEAb can modulate the acid secretion by up-regulating mucous formation in the stomach (Laine et al., 2008).

Taken together the acute experimental models strongly suggest a cytoprotective effect promoted by compounds found in HEAb. Although the presented data are limited by the absence of a $\mathrm{PGE}_{2}$ measurement in the gastric tissue, the findings shown here suggest that HEAb constituents may play a role in the eicosanoids pathway.

\subsubsection{Effect of the HEAb oral daily treatment on cicatrisation and on} myeloperoxidase (MPO) activity in the gastric mucosa of rats submitted acetic acid-induced gastric ulcer

To address the ability of HEAb in accelerating the healing process the acetic acid model was employed (Okabe et al., 1971). This protocol is also very well known for evaluating the cicatrisation properties of the sample tested, which is usually dependent on their ability to promote cytoprotection (Okabe and Amagase, 2005). The model consists in inducing gastric lesion with local instillation of acetic acid onto a delimitated area in the gastric mucosa in the rats and after recovery and checking the initial mean area of lesion. The animals were divided into groups and then experimental therapeutic treatments were initiated up to 14 days after establishment of the ulcer (see experimental data). In order to verify the 
Table 5

Effect of the HEAb (300 mg/kg) oral pre-treatment on gastric mucus adhered to mucosa wall in rats.

\begin{tabular}{|c|c|c|c|c|}
\hline Groups & Dose $(\mathrm{mg} / \mathrm{kg})$ & $n$ & Alcian blue $(\mu \mathrm{g} / \mathrm{ml} / \mathrm{g}$ of tissue $)$ & Increase (\%) \\
\hline Control & - & 6 & $36.8 \pm 3.3$ & - \\
\hline Carbenoxolone & 100 & 6 & $58.5 \pm 3.0^{* * *}$ & 58.9 \\
\hline HEAb & 300 & 6 & $50.0 \pm 3.4^{*}$ & 35.9 \\
\hline
\end{tabular}

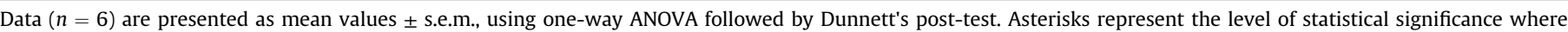
${ }^{*} p<0.05$ and ${ }^{* * *} p<0.001$ compared to control group.

Table 6

Effect of the HEAb (300 mg/kg) intra-duodenal treatment on gastric secretion in rats submitted to pylorus ligation.

\begin{tabular}{|c|c|c|c|c|c|}
\hline Groups & Dose (mg/kg) & $n$ & Gastric secretion (mL) & Inhibition (\%) & Acidity $(\mathrm{pH})$ \\
\hline Control & - & 6 & $0.55 \pm 0.02$ & - & 4.9 \\
\hline Cimetidine & 100 & 5 & $0.29 \pm 0.01^{* *}$ & 47.2 & $5.4^{* * *}$ \\
\hline $\mathrm{HEAb}$ & 300 & 6 & $0.53 \pm 0.06$ & 3.6 & $5.2^{* *}$ \\
\hline
\end{tabular}

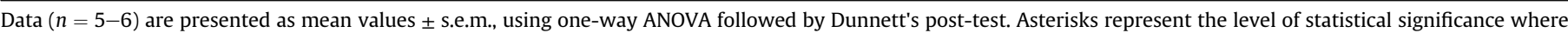
${ }^{* *} p<0.01$ and ${ }^{* * *} p<0.001$ compared to control group.

progression of the healing process, the animals were sacrificed at two different time points (after 7 and 14 days of treatment). Importantly, no signs of toxicity were observed after 7 and 14 consecutive days of HEAb oral treatment (data not shown).

HEAb treatment decreased the ulcer area after 7 and 14 days of treatment, similarly to lansoprazole (Fig. 1A-C). Remarkably, HEAb demonstrated equivalent capacity to lansoprazole in protecting and recovering gastric mucosa in this study.

It is known from literature that lansoprazole strongly reduces the hydrogen ion release to gastric lumen, reducing then the ability of pepsin in damaging gastric mucosa and, consequently, preventing the injured area from acid and pepsin insults resulting in cell proliferation and healing (Kobayashi et al., 2010), most likely by activating the up-regulation of COX-2 additionally to its main antisecretory effect (Tsuji et al., 2002). Similarly, a study from our group had already demonstrated the cytoprotective properties of natural compounds accelerating the resolution of gastric ulcer by elevating PGs release as a consequence of COX-2 up-regulation (de-Faria et al., 2012a).

As aforementioned, HEAb promotes cytoprotection by inducing gastric mucous formation (Table 5) which is believed to be controlled by, allegedly, restoring PG levels necessary to maintain gastric homeostasis (Table 4). Consistent with the presented data, HEAb provides acceleration of the healing process in the early stage (Fig. 1A) probably by activating (or allowing) an inflammatory pathway.

Indeed, HEAb presented increased MPO activity in the gastric mucosa after 7 days of treatment and then decreased MPO activity after 14 days (Table 7). This phenomenon suggests the neutrophils activation at the gastric mucosa of rats treated by HEAb may contributed to the healing process afterward.

These results are consistent with the literature whereas neutrophil infiltration may take an important place in modulating gastric damage during early stages. At the first, eicosanois, i.e. leukotrienes (LT) b4, induce neutrophil recruitment and activation. On the other hand, progstaglandins (i.e. $\mathrm{PGE}_{2}$ ) shift neutrophil toward an anti-inflammatory profile during the resolution stages of inflammation, evidenced by resolving lipoxins (Dennis and Norris, 2015; Takeuchi, 2012).

One can argue that control group presented same MPO activity at early stage (7 days), but no healing improvement is verified afterward. In contrast, HEAb seems to modulate the cicatrisation beyond the neutrophil activation. This may be due to the absence of molecules controlling this mechanism, which would be present in the group treated with HEAb.

\subsection{Phytochemical investigation of the bioactive extract}

In order to obtain comprehensive information on the constituents of the hydroethanolic extract (HEAb) it was submitted to an indepth phytochemical investigation. Metabolite profiling was performed in order to obtain information on its metabolite composition and targeted isolation of all potential original metabolites was performed by preparative chromatography (MPLC).

\subsection{LC-PDA-MS analysis of the HEAb extract and isolation of the compounds}

For dereplication purposes, the HEAb extract was analysed by HPLC-PDA-MS (Fig. 2) and its metabolite profile was compared to
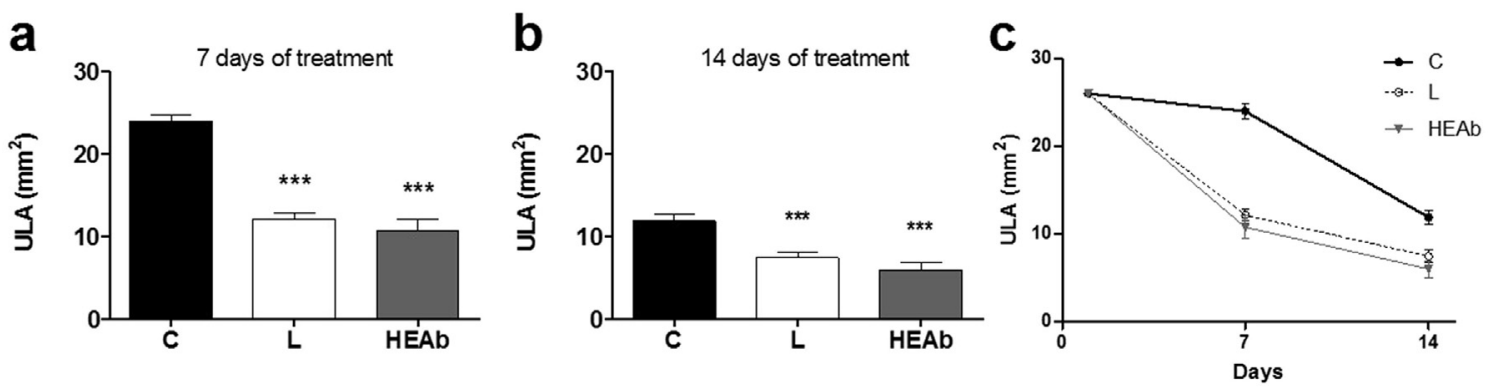

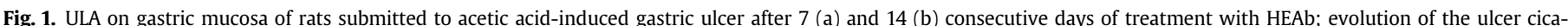

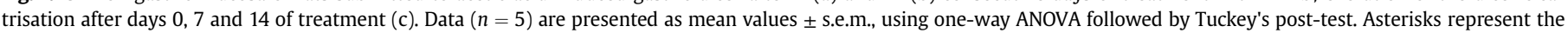
level of statistical significance where ${ }^{* * *} p<0.001$ compared to control group. 
Table 7

Effect of the HEAb $(300 \mathrm{mg} / \mathrm{kg}$ ) oral daily treatment on MPO activity in the gastric mucosa of rats submitted acetic acid-induced gastric ulcer.

\begin{tabular}{|c|c|c|c|c|}
\hline Groups & Dose (mg/kg) & $n$ & MPO activity (U/mg of protein) & Changes (\%) \\
\hline \multicolumn{5}{|c|}{ After 7 days of treatment } \\
\hline Control & - & 5 & $0.15 \pm 0.03$ & - \\
\hline Lansoprazole & 60 & 5 & $0.07 \pm 0.01$ & $(-) 53$ \\
\hline $\mathrm{HEAb}$ & 300 & 5 & $0.19 \pm 0.02$ & $(+) 26$ \\
\hline \multicolumn{5}{|c|}{ After 14 days of treatment } \\
\hline Control & - & 5 & $0.16 \pm 0.01$ & - \\
\hline Lansoprazole & 60 & 5 & $0.11 \pm 0.01^{*}$ & $(-) 31$ \\
\hline HEAb & 300 & 5 & $0.10 \pm 0.01^{* *}$ & $(-) 37$ \\
\hline
\end{tabular}

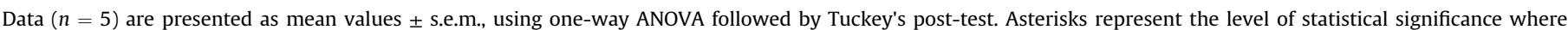
${ }^{*} p<0.05$ and ${ }^{* *} p<0.01$ compared to control group.

that of a dichloromethane extract previously investigated (da Rocha et al., 2014). This allowed the unambiguous identification of previously isolated compounds brachydin A (4) (Rt: $41.5 \mathrm{~min}, \mathrm{UV} \lambda_{\max }$ $\left.(\log \varepsilon) 266(4.42) \mathrm{nm}, m / z 525[\mathrm{M}+\mathrm{H}]^{+}\right)$, brachydin B (11) (Rt: $55.7 \mathrm{~min}$, UV $\left.\lambda_{\max }(\log \varepsilon) 254(4.44) \mathrm{nm}, m / z 539[\mathrm{M}+\mathrm{H}]^{+}\right)$and brachydin C (12) (Rt: $58.5 \mathrm{~min}$, UV $\lambda_{\max }(\log \varepsilon) 266(4.22) \mathrm{nm}, m / z$ $509[\mathrm{M}+\mathrm{H}]^{+}$) (Fig. 2). The HPLC-PDA-MS analysis also revealed that all peaks (3, 5-10) (UV band at 265 with shoulder at $300 \mathrm{~nm}$ ) at the exception of 1, 2 (single UV band at $280 \mathrm{~nm}$ ) presented closely related UV PDA spectra to that of the known dimeric flavonoids (4, 11, 12). According to the protonated molecular ions recorded in ESIMS the MW of these flavonoids were significantly higher than that of $4,11,12$ and ranges from $m / z 701[\mathrm{M}+\mathrm{H}]^{+}$to $915[\mathrm{M}+\mathrm{Na}]^{+}$. All these compounds presented a neutral loss of 176 Da characteristic a glucuronic acid moieties, either directly from the molecular ions ( $\mathbf{3}$, 6, 7 and 10) or from subsequent fragments $(5,8$ and 9$)$, suggesting the presence of glucuroconjugates (see Table 1, Supporting information). In addition, the known aglycones presented characteristic 1,3B + fragments (Domon and Costello, 1988) at $m / z 271$ for $\mathbf{4}, m / z 285$ for 11, and $m / z 255$ for 12 resulting from a fragmentation between $0-12 / C-12 \mathrm{a}$ and $\mathrm{C}-7 / \mathrm{C}-6 \mathrm{a}$ (Table $1 \mathrm{~S}$ ). The mass difference between these ${ }^{1,3} \mathrm{~B}^{+}$fragment ions was related to a change of substitution at C-4" on C-ring (a hydroxyl (4), a methoxyl (11) and a proton (12)) (see Table 1S, Supporting information). Using these characteristic ions it was possible to hypothesise that 3, 7 and 8 were glucuronide derivatives of the aglycone $\mathbf{4}$, compounds 6 and 9 were glucuronides of $\mathbf{1 1}$, while $\mathbf{5}$ and $\mathbf{1 0}$ were glucuronides of $\mathbf{1 2}$. The exact position of the sugars residues could however not be determined based on these data only. On the other hand, $\mathbf{1}, \mathbf{2}$ presented UV, MS and MS/MS data that differ from 3, 5-10, suggesting that these compounds were other type of phenolic derivatives. These on-line data were compared to that of compounds previously isolated in the Arrabidaea genus and indicated that they were probably original NPs.

In order to unambiguously identify each compound, 1-3, 5-10 were isolated by a direct transfer of the analytical HPLC conditions to medium pressure liquid chromatography (MPLC) (Challal et al., 2015). Prior to this the known aglycones were selectively removed by a liquid-liquid partition of the crude HEAb extract (see chromatograms in Fig. 2). As expected from the dereplication results these nine compounds $(\mathbf{1}-\mathbf{3}, \mathbf{5}-\mathbf{1 0})$ were found to be original NPs (Fig. 3).

\subsection{Isolated compounds}

The high-resolution (HR)-ESIMS of 3 revealed a $[\mathrm{M}-\mathrm{H}]^{-}$ion at $\mathrm{m} /$ $z$ 875.2426, corresponding to $\mathrm{C}_{44} \mathrm{H}_{43} \mathrm{O}_{19}$. As suspected by the dereplication results, the NMR spectra of $\mathbf{3}$ were closely related to those of brachydin A (da Rocha et al., 2014). The ${ }^{1} \mathrm{H}$ NMR spectrum of 3 exhibited signals for 13 aromatic protons, two ethylenic protons, two oxygenated methines, two aliphatic methines, and two methoxy groups, which were also confirmed by HSQC. The different aromatic signals belonged to four independent rings, named A, B, C and $\mathrm{D}$. The two meta-coupled protons belonging to A-ring were identified by their HMBC correlations with C- 1 and C-4a (at $\delta_{C} 160.5$ and 157.3 , respectively), these carbons also exhibited a ${ }^{3} \mathrm{~J}_{\mathrm{CH}}$ coupling with $\mathrm{H}-12 \mathrm{a}$. The two remaining meta-coupled protons $(\mathrm{H}-$ 9 and $\mathrm{H}-11)$ at $\delta_{\mathrm{H}} 6.35$ and 6.29 were positioned on the B-ring because they shared with $\mathrm{H}-7$ the same HMBC correlations with C7-a, C-8 and C-11a (at $\delta_{C} 104.4,159.7$ and 154.8, respectively). The two ortho-coupled protons $\mathrm{H}-2^{\prime \prime},-6^{\prime \prime}$ and $\mathrm{H}-3^{\prime \prime},-5^{\prime \prime}$ at $\delta_{\mathrm{H}} 7.05$ and 6.64 were placed on the $C$-ring due to their correlation with $C-\beta\left(\delta_{C}\right.$ 131.7). The five remaining aromatic protons belonged to the $D$-ring as shown by their HMBC correlations with $\mathrm{C}-6\left(\delta_{\mathrm{C}} 78.0\right)$. The HMBC correlations allowed positioning of the two methoxy groups at $\delta_{\mathrm{H}} /$ $\delta_{C} 3.83 / 56.0$ and $3.65 / 55.9$ at $C-1$ and C-8, respectively. The relative configuration of the fused benzopyran rings, established based on scalar and dipolar couplings, was similar to that of Brachydin A. The presence of glucuronides, deduced from MS/MS analysis, was confirmed by two anomeric protons doublet signals $(J=6.5 / 7.1 \mathrm{~Hz})$ at $\delta_{H} 4.94\left(\delta_{C} 101.9\right)$ and $4.99\left(\delta_{C} 102.1\right)$. They were confirmed to be $\beta$-glucuronic acids based on the chemical shifts and coupling constants of the sugar protons. The HMBC correlations from each anomeric proton to the aromatic carbons at $\delta_{C} 160.8$ and 159.2 confirmed their attachment to the A-ring in C-3 and to the B-ring B in C-10. Consequently, $\mathbf{3}$ was identified as a previously undescribed glycosylated dimeric flavonoid and named brachydin D.

The high-resolution (HR)-ESIMS of 5 revealed a $[\mathrm{M}-\mathrm{H}]^{-}$ion at $\mathrm{m} /$ $z 859.2457$ corresponding to $\mathrm{C}_{44} \mathrm{H}_{43} \mathrm{O}_{18}$. As also revealed by dereplication, $\mathbf{5}$ was thus lacking an oxygen compared to $\mathbf{3}$ which was probably due to a difference of substitution on the aglycone. The NMR spectra of $\mathbf{5}$ indeed confirmed that a phenyl group was linked to $\mathrm{C}-\beta$ instead of a phenol as shown by the aromatic protons at $\delta_{\mathrm{H}}$ $7.23\left(2 \mathrm{H}, \mathrm{m}, \mathrm{H}-2^{\prime \prime}, 6^{\prime \prime}\right), 7.22\left(2 \mathrm{H}, \mathrm{m}, \mathrm{H}-3^{\prime \prime}, 5^{\prime \prime}\right)$ and $7.13(1 \mathrm{H}, \mathrm{t}$, $\left.J=7.0 \mathrm{~Hz}, \mathrm{H}-4^{\prime \prime}\right) .5$ was thus identified as a previously undescribed diglucuronated dimeric flavonoid of the aglycone brachydin C (12) and named brachydin E.

The NMR spectra of $\mathbf{6}$ were close related to brachydin B (da Rocha et al., 2014). The only difference between these compounds was the presence of two $\beta$-glucuronic acids revealed by their anomeric protons at $\delta_{\mathrm{H}} 4.94\left(1 \mathrm{H}, \mathrm{d}, J=6.0 \mathrm{~Hz}, 3-\mathrm{GlcA}-\mathrm{H}-1^{\prime}\right)$ and $4.98\left(1 \mathrm{H}, \mathrm{d}, J=7.0 \mathrm{~Hz}, 10-\mathrm{GlcA}-\mathrm{H}_{-} \mathbf{1}^{\prime}\right)$. The HMBC correlation between the anomeric proton at $\delta_{\mathrm{H}} 4.94$ and the carbon at $\delta_{\mathrm{C}} 160.8$ (C-3) as well as that between $\delta_{\mathrm{H}} 4.98$ and $\delta_{\mathrm{C}} 159.2$ (C-10) confirmed the attachment of the $\beta$-glucuronic acids to $C-3$ and $C-10$ of the aglycone moiety. The high-resolution (HR)-ESIMS of $\mathbf{6}$ revealed a $[\mathrm{M}-\mathrm{H}]^{-}$ion at $m / z$ 889.2586, corresponding to $\mathrm{C}_{45} \mathrm{H}_{45} \mathrm{O}_{19}$, confirming the presence of an aglycone substituted by three methoxy groups and two glucuronic acids. Based on these results, 6 was identified as a previously undescribed diglucuronated dimeric flavonoid and named brachydin $\mathrm{F}$.

The high-resolution (HR)-ESIMS of 7 revealed a $[\mathrm{M}-\mathrm{H}]^{-}$ion at $\mathrm{m} /$ 

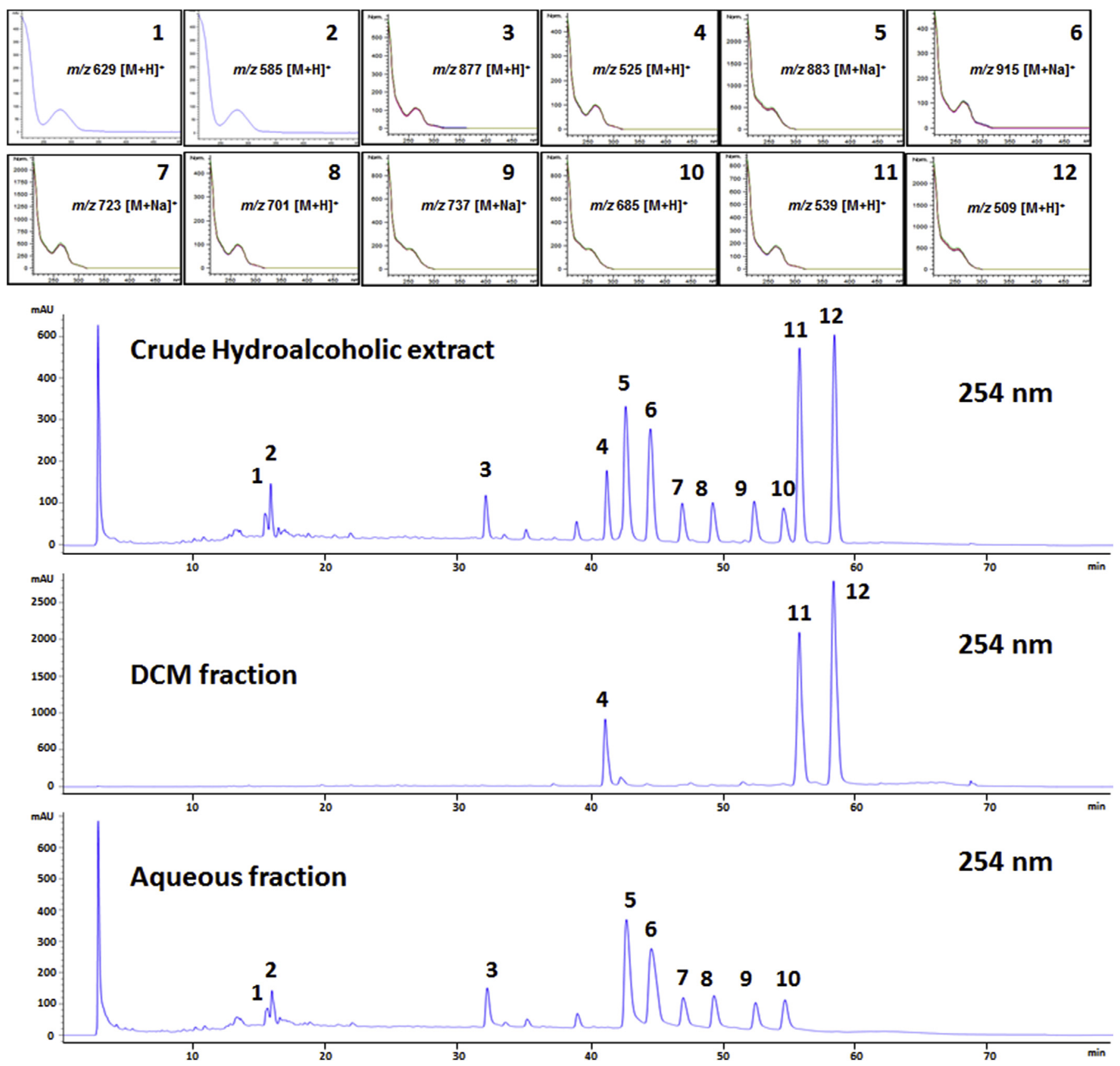

Fig. 2. HPLC-UV-MS analysis of the hydroethanolic extract and dichloromethane and aqueous fractions of the roots of A. brachypoda.

$z$ 699.2072 corresponding to $\mathrm{C}_{38} \mathrm{H}_{35} \mathrm{O}_{13}$. The NMR data of 7 presented the same characteristic signals of a dimeric flavonoid aglycone substituted by two methoxy groups at C- 1 and $\mathrm{C}-8$. In this case the HMBC correlation between the anomeric proton $\delta_{\mathrm{H}} 4.86(1 \mathrm{H}, \mathrm{d}$, $J=7.7 \mathrm{~Hz}, 3-\mathrm{GlcA}-\mathrm{H}-1^{\prime}$ ) with the quaternary carbon $\delta_{\mathrm{C}} 159.8$ (C-3) confirmed the attachment of the $\beta$-glucuronic acid ester to $\mathrm{C}-3$ of the aglycone moiety. The positions $\mathrm{C}-4^{\prime \prime}$ and $\mathrm{C}-10$ were substituted by two free hydroxy groups. Consequently, 7 was identified as an original glucuronated dimeric flavonoid and named brachydin $\mathrm{G}$.

Compound $\mathbf{8}$ presented the same molecular formula as $\mathbf{7}$ $\left(\mathrm{C}_{38} \mathrm{H}_{36} \mathrm{O}_{13}\right)$. The NMR data of $\mathbf{8}$ were also closely related to those of 7 , suggesting the presence of a dimeric flavonoid aglycone substituted by two methoxy groups and one $\beta$-glucuronic acid. According to the HMBC correlations between the anomeric proton at $\delta_{\mathrm{H}} 4.9\left(1 \mathrm{H}, \mathrm{d}, J=7.5 \mathrm{~Hz}, 10-\mathrm{GlcA}-\mathrm{H}-1^{\prime}\right)$ and $\delta_{\mathrm{C}} 159.5(\mathrm{C}-10)$, the glucuronic moiety is attached to ring $\mathrm{A}$ at $\mathrm{C}-10$. Based on these results, $\mathbf{8}$ was identified as a previously undescribed glycosylated dimeric flavonoid and named brachydin $\mathrm{H}$.

The high-resolution (HR)-ESIMS of $\mathbf{9}$ showed a $[\mathrm{M}-\mathrm{H}]^{-}$ion at $\mathrm{m} /$ $z 713.2256$ corresponding to $\mathrm{C}_{39} \mathrm{H}_{37} \mathrm{O}_{13}$. The ${ }^{1} \mathrm{H}$ and ${ }^{13} \mathrm{C}$ NMR of $\mathbf{9}$ were similar to those of $\mathbf{7}$ and $\mathbf{8}$ for the aglycone moiety and most of the sugar signals. An additional signal at $\delta_{\mathrm{H}} 3.71\left(3 \mathrm{H}, \mathrm{s}, \mathrm{OCH}_{3}\right)$ was attributed to a methoxy group that exhibited an HMBC correlation with the quaternary carbon at $\delta_{C} 159.4$ and suggesting its attachment on the ring $\mathrm{C}$ at $\mathrm{C}-4^{\prime \prime}$. Based on these results, 9 was identified as a previously undescribed glycosylated dimeric flavonoid and named brachydin I.

The NMR spectra of $\mathbf{1 0}$ were closely related to brachydin C 


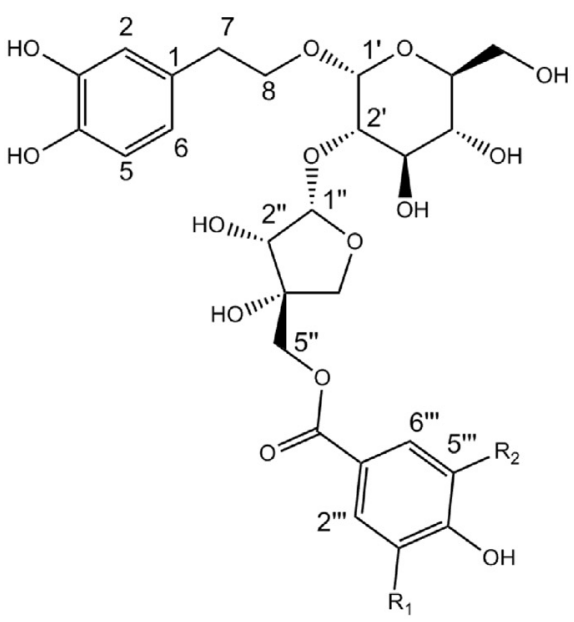

1): $\mathrm{R}_{1}=\mathrm{OCH}_{3}$ and $\mathrm{R}_{2}=\mathrm{OCH}_{3}$

2): $\mathrm{R}_{1}=\mathrm{OH}$ and $\mathrm{R}_{2}=\mathrm{H}$

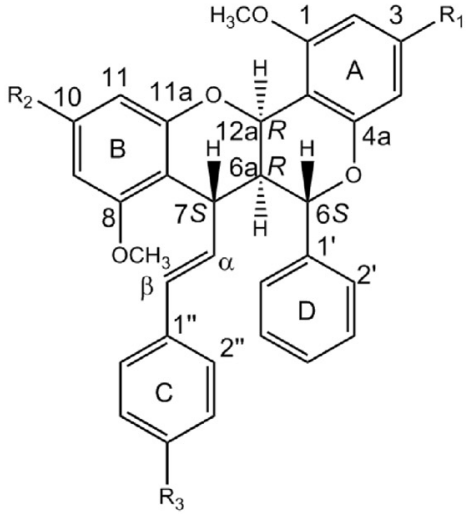

3): $\mathrm{R}_{1}=$ GlucA, $\mathrm{R}_{2}=$ GlucA, $\mathrm{R}_{3}=\mathrm{OH}$

4): $\mathrm{R}_{1}=\mathrm{OH}, \mathrm{R}_{2}=\mathrm{OH}, \mathrm{R}_{3}=\mathrm{OH}$

5): $R_{1}=$ GlucA, $R_{2}=$ GlucA, $R_{3}=H$

6): $R_{1}=$ GlucA, $R_{2}=$ GlucA, $R_{3}=O \mathrm{OCH}_{3}$

7): $\mathrm{R}_{1}=$ GlucA, $\mathrm{R}_{2}=\mathrm{OH}, \mathrm{R}_{3}=\mathrm{OH}$

8): $\mathrm{R}_{1}=\mathrm{OH}, \mathrm{R}_{2}=\mathrm{GlucA}, \mathrm{R}_{3}=\mathrm{OH}$

9): $\mathrm{R}_{1}=\mathrm{OH}, \mathrm{R}_{2}=\mathrm{GlucA}, \mathrm{R}_{3}=\mathrm{OCH}_{3}$

10): $R_{1}=O H, R_{2}=$ GlucA, $R_{3}=H$

11): $\mathrm{R}_{1}=\mathrm{OH}, \mathrm{R}_{2}=\mathrm{OH}, \mathrm{R}_{3}=\mathrm{OCH}_{3}$

12): $\mathrm{R}_{1}=\mathrm{OH}, \mathrm{R}_{2}=\mathrm{OH}, \mathrm{R}_{3}=\mathrm{H}$

Fig. 3. Structures of the compounds isolated from the hydroalcoholic extract of A. brachypoda.

previously isolated from the DCM extract (da Rocha et al., 2014). The high-resolution (HR)-ESIMS of $\mathbf{1 0}$ showed a $[\mathrm{M}-\mathrm{H}]^{-}$ion at $\mathrm{m} / z$ 683.2158 corresponding to $\mathrm{C}_{38} \mathrm{H}_{35} \mathrm{O}_{12}$, suggesting the presence of an aglycone substituted by two methoxy groups and one glucuronic acid. Two singlets at $\delta_{\mathrm{H}} 3.65\left(3 \mathrm{H}, \mathrm{s}, \mathrm{OCH}_{3}\right)$ and $\delta_{\mathrm{H}} 3.80\left(3 \mathrm{H}, \mathrm{s}, \mathrm{OCH}_{3}\right)$ confirmed the presence of two methoxy groups. An anomeric proton at $\delta_{\mathrm{H}} 5.00(1 \mathrm{H}, \mathrm{d}, J=7.3 \mathrm{~Hz})$ with an $\mathrm{HMBC}$ correlation with the carbon at $\delta_{C} 159.6(\mathrm{C}-10)$ indicated the attachment of the $\beta$ glucuronic acid at C-10. 10 was identified as a previously undescribed glycosylated dimeric flavonoid and named brachydin J.

The absolute configuration of dimeric flavonoids 3-12 was established by comparing experimental and calculated ECD spectra. In the experimental ECD spectra all compounds showed two negative Cotton effects (CE) at 215 and 225 (sh) nm. These features were likely due to $\pi \rightarrow \pi^{*}$ transitions in the extended $\pi$-system of benzyl moiety. All of these compounds differ in substitution by addition of hydroxyl, methoxy and glucuronic acid moieties, since these groups have no influence in ECD spectra, therefore compound 4 was selected as model for time dependent density functional theory (TDDFT) calculation of the ECD spectrum (Fig. 4). For this purpose, the 3D structure of $\mathbf{4}$ constructed based on NMR data $(6 S, 7 S, 6 \mathrm{a} R, 12 \mathrm{a} R)$ was submitted to a systematic conformational analysis followed by geometry optimization. Calculation of free energies indicated the presence of eight conformers, $1 \mathrm{a}(25.74 \%), 1 \mathrm{~b}$ (25.73\%), 1c (24.28\%), 1d (6.13\%), 1e (5.56\%), 1f (5.62\%), 1g (5.51\%) and $1 \mathrm{~h}(1.42 \%)$, which are different in orientation of the phenyl ethane and benzyl moieties (Fig. 5). The calculated ECD spectrum of
4 closely matched with the experimental data, in particular negative CEs in the $275 \mathrm{~nm}$ and $215 \mathrm{~nm}$ regions, and a positive CE in the region of $200 \mathrm{~nm}$. Differences between calculated and experimental spectra were apparently due to minor difference between calculated and solution conformers of this flexible molecule whereas the other stereoisomer showed completely different pattern for ECD spectrum. Thus, the configuration of $\mathbf{4}$ and of all dimeric flavonoids was established as $6 S, 7 S, 6 \mathrm{a} R, 12 \mathrm{a} R$.

Compound $\mathbf{1}$ and $\mathbf{2}$ were isolated as a mixture as an amorphous white solid. The high-resolution (HR)-ESIMS of 1 revealed a [M-H ${ }^{-}$ ion at $m / z$ 627.1923, corresponding to $\mathrm{C}_{28} \mathrm{H}_{35} \mathrm{O}_{16}$. The ${ }^{1} \mathrm{H}$ and ${ }^{13} \mathrm{C}$ NMR spectra of $\mathbf{1}$ revealed the presence of a syringic acid moiety as indicated by the aromatic signal at $\delta_{\mathrm{H}} 7.25$ integrating for two protons $\left(\mathrm{H}-2^{\prime \prime \prime}\right.$ and $\left.\mathrm{H}-6^{\prime \prime \prime}\right)$, the singlet at $\delta_{\mathrm{H}} 3.78 / \delta_{\mathrm{C}} 56.1$ accounting for two methoxy groups, the ester signal at $\delta_{\mathrm{C}} 165.5\left(\mathrm{C}-6^{\prime \prime \prime}\right)$ and three quaternary sp2-hybridized aromatic carbons $\left[\delta_{\mathrm{C}} 147.5\left(\mathrm{C}-3^{\prime \prime \prime}\right.\right.$ and $\left.\mathrm{C}-5^{\prime \prime \prime}\right), 140.9\left(\mathrm{C}-4^{\prime \prime \prime}\right)$, and $\left.119.3\left(\mathrm{C}-1^{\prime \prime \prime}\right)\right]$. The presence of sugars, which was suspected upon MS/MS analysis, was confirmed by the two signals at $\delta_{\mathrm{H}} / \delta_{\mathrm{C}} 4.19(1 \mathrm{H}, \mathrm{d}, J=8.0 \mathrm{~Hz}) / 101.1$ and $5.36 / 108.1$ corresponding to two anomeric protons. Based on chemical shifts and coupling constants, the first sugar was identified as a glucose and the second one to an apiofuranose both with a $\beta$ configuration. These chemical shifts were in good agreement with those described for the hydroquinone diglycoside ester seguinoside $\mathrm{K}$ (Zhong et al., 1999). The HMBC correlation between the methylene protons at $\delta_{H}$ $4.25\left(1 \mathrm{H}, \mathrm{d}, J=11.1 \mathrm{~Hz}, \mathrm{H}-5 \mathrm{~b}^{\prime \prime}\right), 4.39\left(1 \mathrm{H}, \mathrm{d}, J=11.1 \mathrm{~Hz}, \mathrm{H}-5 \mathrm{a}^{\prime \prime}\right)$ and the carbonyl at $\delta_{C} 165.5\left(C-7^{\prime \prime \prime}\right)$ confirmed the attachment of the 


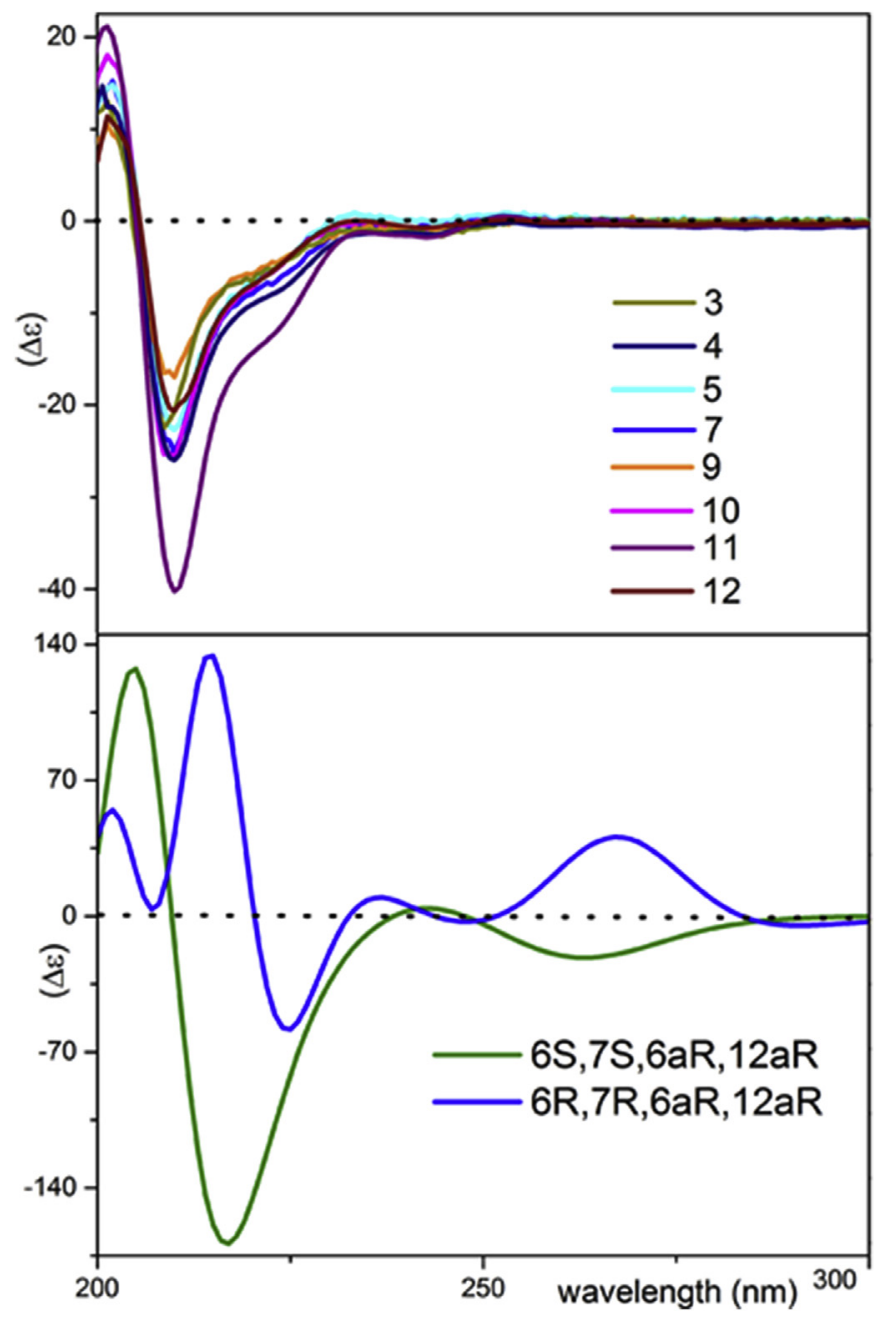

Fig. 4. Comparison of the experimental ECD spectra of dimeric flavonoids (top) and calculated spectra of the two stereoisomers $(6 S, 7 S, 6 \mathrm{a} R, 12 \mathrm{a} R)$ and $(6 R, 7 R, 6 \mathrm{a} R, 12 \mathrm{a} R)$ stereoisomers (bottom).

syringic acid ester to $\mathrm{C}-5^{\prime \prime}$ of the apiofuranose moiety. Moreover, the correlation between the anomeric proton at $\delta_{\mathrm{H}} 5.36\left(\mathrm{H}-1^{\prime \prime}\right)$ and the carbon at $\delta_{\mathrm{C}} 75.5\left(\mathrm{C}-2^{\prime}\right)$ established the linkage of the apiofuranose to the $\mathrm{C}-2^{\prime \prime}$ of the glucose moiety. The ${ }^{1} \mathrm{H}$ NMR spectrum also shows an ABX system at $\delta_{\mathrm{H}} 6.31(1 \mathrm{H}, \mathrm{d}, J=8.0,2.0 \mathrm{~Hz}, \mathrm{H}-6), 6.55$ $(1 \mathrm{H}, \mathrm{d}, J=8.0 \mathrm{~Hz}, \mathrm{H}-5), 6.54(1 \mathrm{H}, \mathrm{d}, J=2.0 \mathrm{~Hz}, \mathrm{H}-2)$, and two methylene protons at $\delta_{\mathrm{H}} 2.56(2 \mathrm{H}, \mathrm{t}, J=7.8 \mathrm{~Hz}, \mathrm{H}-7)$ and $3.38(1 \mathrm{H}, \mathrm{m}$, $\mathrm{H}-8 \mathrm{a}) / 3.78$ (1H, m, H-8b) attributed to a hydroxytyrosol moiety (3,4-dihydroxyphenylethanol). The HMBC correlations between the methylene protons at $\delta_{\mathrm{H}} 3.38 / 3.78\left(\mathrm{CH}_{2}-8\right)$ and the anomeric proton at $\delta_{\mathrm{C}} 101.1\left(\mathrm{C}-1^{\prime}\right)$ confirmed the attachment of the hydroxytyrosol to $\mathrm{C}-1^{\prime}$ of the glucose moiety. Based on these results, 1 was identified as a (3,4-dihydroxyphenyl)ethyl 2-O-[5-O-(4-hydroxy-3,5dimethoxybenzoyl)- $\beta$-D-apiofuranosyl]- $\beta$-D glucopyranoside), which is an original phenylethanoid glycoside derivative. The HRESIMS of 2 revealed a $[\mathrm{M}-\mathrm{H}]^{-}$ion at $m / z 583.1670$, corresponding to $\mathrm{C}_{26} \mathrm{H}_{31} \mathrm{O}_{15}$. Its ${ }^{1} \mathrm{H}$ NMR was similar to that of $\mathbf{1}$ except that $\mathbf{2}$ contained a protocatechuic acid moiety instead of a syringic acid as seen by the signals at $\delta_{\mathrm{H}} 7.46\left(1 \mathrm{H}, \mathrm{d}, J=1.8 \mathrm{~Hz}, \mathrm{H}-2^{\prime \prime \prime}\right), 6.86(1 \mathrm{H}, \mathrm{d}$, $\left.J=3 \mathrm{~Hz}, \mathrm{H}-5^{\prime \prime \prime}\right)$ and $7.52\left(1 \mathrm{H}, \mathrm{d}, J=8.3,1.8 \mathrm{~Hz}, \mathrm{H}-6^{\prime \prime \prime}\right)$. Based on these results, 2 was identified as a (3,4-dihydroxyphenyl)ethyl 2-O-[5-O(3,4-dihydroxybenzoyl)- $\beta$-D-apiofuranosyl]- $\beta$-D-glucopyranoside), which is a previously undescribed phenylethanoid glycoside derivative.

\section{Conclusions}

Our findings indicated that HEAb present anti-ulcer activity equivalent to lansoprazole, the drug of first choice for the therapy of peptic ulcers in clinical settings. The extract is mainly composed by a series of unusual dimeric glycosylated flavonoids as well as their aglycones. These unique phenolic compounds from $A$. brachypoda are most probably implicated in the biological activity. Further studies need to be performed to understand the metabolisation of such compounds and determine if the glycosides per se, the aglycones or the metabolites from the aglycones are responsible for the anti-ulcer effects recorded in vivo. A thorough evaluation of the in vivo biological activity of the isolated glycosylated compounds as well their corresponding aglycones after their isolation at large scale will be the topic of future investigations to further understand how the constituents of $A$. brachypoda perform their gastroprotective effect.

\section{Experimental}

\subsection{General procedures and instrumentation}

The optical rotations were measured in methanol on a JASCO polarimeter in a $1 \mathrm{~cm}$ tube. The UV spectra were measured on a Hach UV-vis DR/4000 instrument. ECD spectra were recorded in $\mathrm{MeOH}$ with a Chirascan CD spectrometer (Applied Photophysics). The NMR spectroscopic data were recorded on a $500 \mathrm{MHz}$ Varian Inova NMR spectrometer (Varian, Palo Alto, CA, USA). Chemical shifts are reported in parts per million $(\delta)$ using the residual $\mathrm{CD}_{3} \mathrm{OD}$ signal $\left(\delta_{\mathrm{H}} 3.31 ; \delta_{\mathrm{C}} 49.0\right)$ as the internal standard for both ${ }^{1} \mathrm{H}$ and ${ }^{13} \mathrm{C}$ NMR; the coupling constants $(J)$ are reported in $\mathrm{Hz}$. Complete structural assignments were performed based on 2D experiments (COSY, NOESY, edited-HSQC and HMBC). HRESIMS data were obtained with a Micromass LCT Premier time-of-flight mass spectrometer using an electrospray ionization (ESI) interface (Waters, Milford, MA, USA). The MS ${ }^{\mathrm{n}}$ data were obtained with a LTQ-XL ion trap mass spectrometer using an electrospray ionization (ESI) interface (Thermo Ficher Scientific, Waltham, MA, USA). Analytical HPLC was performed using a HP 1100 system equipped with a photodiode array detector (Agilent Technologies, Santa Clara, CA, USA). The MPLC was performed using a Büchi system equipped with a C-660 modules pump, a UV detector C-640 and fraction collector C-684 from Büchi (Flawil, Switzerland). The system was controlled by the software Sepacore Control.

\subsection{Plant material}

Samples of A. brachypoda D. C. Bureau (Bignoniaceae) roots were collected in April 2014 at Sant'Ana da Serra farm João Pinheiro, Minas Gerais, Brazil (Location: $17^{\circ} 44^{\prime} 45^{\prime \prime} \mathrm{S}, 46^{\circ} 10^{\prime} 44^{\prime \prime} \mathrm{W}$ ). The plant was identified at the ICEB of the José Badine Herbarium of Federal University of Ouro Preto by Prof. Maria Cristina Teixeira Braga Messias. A voucher specimen ( $\left.n^{\circ} 17935\right)$ has been deposited at the Herbarium of the Federal University of Ouro Preto, Brazil.

\subsection{Plant extraction}

The dried roots (1000g) were successively extracted by percolation, at room temperature, with EtOH-H20 70\%. The crude ethanolic extract was obtained after filtration and evaporated to dryness under vacuum at approximately $40^{\circ} \mathrm{C}$, yielding $200.0 \mathrm{~g}$ of hydroethanolic extract.

\subsection{Animals}

Male Wistar rats Unib: WH (150-250 g) obtained from the 


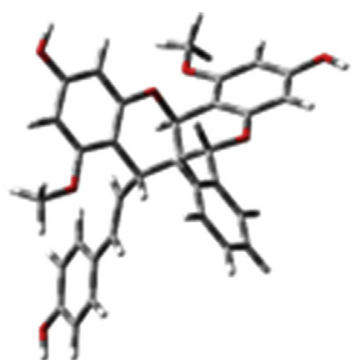

a, $25.74 \%$

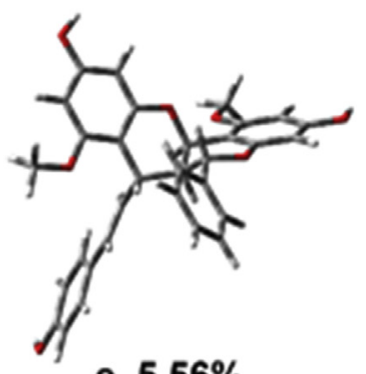

e, $5.56 \%$

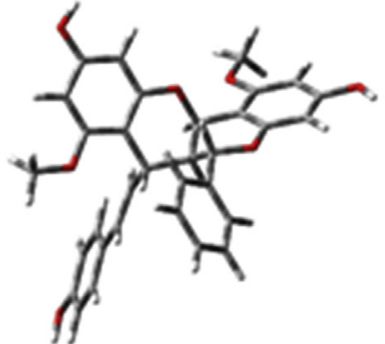

b, $25.73 \%$

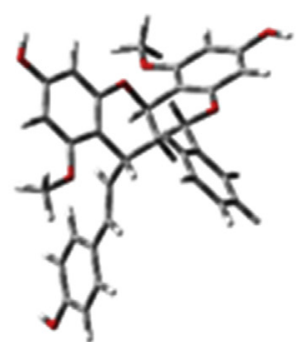

c, $24.28 \%$

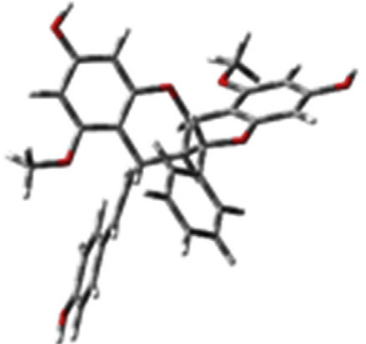

d, $6.13 \%$

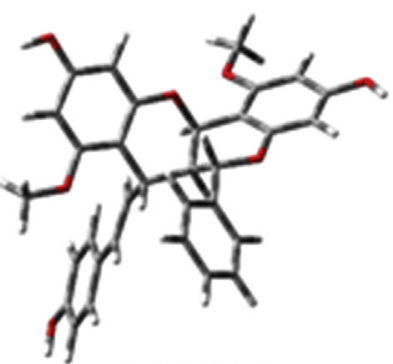

f, $5.62 \%$

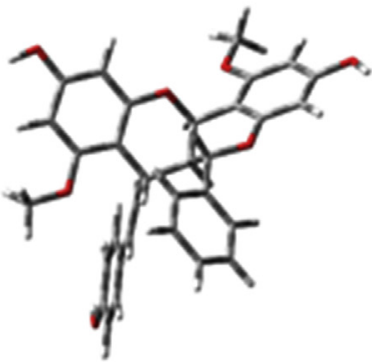

g, $\mathbf{5 . 5 1} \%$

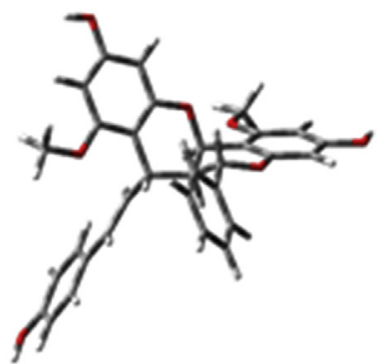

h, $1.42 \%$

Fig. 5. Energy-minimized conformers of 4 using DFT at the B3LYP/6-31G** level.

breeding facility of the State University of Campinas (CEMIB/UNICAMP), were used. The animals were fed a certified Nuvilab ${ }^{\circledR}$ (Nuvital) diet with free access to tap water under standard conditions of $12 \mathrm{~h}$ dark-12 h light, humidity $(60.0 \pm 1.0 \%)$ and temperature $(21.0 \pm 1 \%)$. The UNICAMP Institutional Animal Care and Use Committee (CEUA), following the recommendations of the Canadian Council on Animal Care (Olfert et al., 1993), approved all of the employed protocols (approval certificate \#2743-1) on May 21st, 2012.

\subsection{Pharmacological procedures}

\subsubsection{Ethanol induced gastric ulcer}

The rats were divided into six treatment groups, fasted $24 \mathrm{~h}$ prior to receiving an oral dose of the vehicle (saline $10 \mathrm{ml} / \mathrm{kg}$ ) (Synth, Diadema, SP, Brazil), lansoprazole (60 mg/kg) (Medley, Campinas, SP, Brazil) and HEAb (10, 30, 100 and $300 \mathrm{mg} / \mathrm{kg}$ ). After $60 \mathrm{~min}$, all groups were orally treated with $1 \mathrm{~mL}$ of absolute ethanol (Merck KGaA, Darmstadt, Germany) for the gastric ulcer induction. One hour later, the animals were sacrificed and their stomachs excised and gastric contents aspirated. Each stomach was incised along the greater curvature and examined for linear haemorrhagic lesions in the glandular region (Robert et al., 1979). Then, the stomachs were photographed and the area of the lesions, namely ulceration lesion area (ULA), was measured $\left(\mathrm{mm}^{2}\right)$ by the program AVSoft BioView (AVSoft Softwares Laboratoriais, Campinas, SP, Brazil).

\subsubsection{Role of endogenous nitric oxide (NO) and sulfhydril compounds (SHs)}

The model described by Matsuda et al. (1999) was employed in order to verify the involvement of NO and GSH on HEAb gastroprotective effect. Male rats were divided into 6 groups and pretreated with saline (i.p. or s.c., $5 \mathrm{mg} / \mathrm{kg}$ ), NEM (N-ethylmaleimide, s.c., $10 \mathrm{mg} / \mathrm{kg}$ ) a blocker of SH compounds or L-NAME N $\omega$-Nitro-Larginine methyl ester hydrochloride, i.p., $70 \mathrm{mg} / \mathrm{kg}$ ) an inhibitor of the NO synthesis. Thirty minutes after the pre-treatment, the animals were treated with (p.o.) vehicle, carbenoxolone $(100 \mathrm{mg} / \mathrm{kg}$ ) or HEAb (300 mg/kg). After $60 \mathrm{~min}$, all groups were administered absolute ethanol (10 ml $/ \mathrm{kg}$ ) (Merck KGaA, Darmstadt, Germany) to induce gastric ulcers. One hour after receiving ethanol the rats were sacrificed and stomachs removed for determination of the gastric lesions as afore mentioned. All reagents used in this experiment, except the ethanol, were purchased from Sigma-Aldrich (St. Louis, MO, USA).

\subsubsection{Indomethacin-induced gastric ulcer}

Indomethacin-induced gastric ulcer was conducted accordantly to Whittle (1975). Animals were fasted for $24 \mathrm{~h}$ and divided randomly into three experimental groups. Firstly, animals were orally treated with saline, carbenoxolone $(100 \mathrm{mg} / \mathrm{kg})$ or HEAb (300 mg/kg). After $30 \mathrm{~min}$, indomethacin (s.c. $30 \mathrm{mg} / \mathrm{kg}$ ), dissolved in $5 \%$ sodium bicarbonate solution, was administered for all animals. Four hours after indomethacin administration, rats were sacrificed and their stomachs removed for the determination of the gastric lesions as described above. All reagents used in this experiment were purchased from Sigma-Aldrich.

\subsubsection{Determination of the mucus adhering to gastric mucosal wall}

Rats were divided into three groups. After fasting animals for $24 \mathrm{~h}$, HEAb (300 mg/kg), carbenoxolone $(100 \mathrm{mg} / \mathrm{kg}$ ) or vehicle were orally administered. Sixty minutes later, under anaesthesia, the abdomen was incised, the pylorus ligated, and then abdomen stitched. The animals were allowed to recover and sacrificed $4 \mathrm{~h}$ after the surgery. The stomach was immersed in $10 \mathrm{~mL}$ of $0.02 \%$ Alcian blue $0.16 \mathrm{M}$ sucrose/0.05 M sodium acetate solution (Synth, Diadema, SP, Brazil), pH 5.8, and incubated for $24 \mathrm{~h}$ at $20^{\circ} \mathrm{C}$. The Alcian blue binding extract was centrifuged at $2000 \mathrm{~g}$ for $10 \mathrm{~min}$. The absorbency of supernatant was measured at $598 \mathrm{~nm}$. The free mucus in the gastric content was calculated from the amount of Alcian blue binding the gastric mucus $[\mu \mathrm{g} / \mathrm{ml} / \mathrm{g}$ of glandular tissue] (Corne et al., 1974). 


\subsubsection{Determination of the gastric acid secretion}

The determination of gastric secretion was performed using the method of Shay et al. (1945), with a few modifications. After $24 \mathrm{~h}$ of fasting, rats were divided into groups, anesthetized and the abdomen was incised and the pylorus ligated. Immediately after the pylorus ligature, vehicle ( $5 \mathrm{ml} / \mathrm{kg}$ ), HEAb $(300 \mathrm{mg} / \mathrm{kg}$ ) or cimetidine $(100 \mathrm{mg} / \mathrm{kg}$ ) were administered intra-duodenally. Four hours later, animals were sacrificed, the abdomen was opened, and placed ligature around the oesophagus. The stomachs were removed and the gastric content collected and drained into a graduated centrifuge tube and centrifuged at $2000 \mathrm{~g}$ for $15 \mathrm{~min}$ at room temperature. The supernatant volume was measured and the $\mathrm{pH}$ was recorded with a digital pH meter (PA 200, Marconi S.A., Piracicaba, SP, Brazil).

\subsubsection{Acetic acid-induced gastric ulcer}

Acetic acid-induced gastric ulcer was performed as described by (Okabe et al., 1971). Under anaesthesia, laparotomy was performed in all through a midline-epigastric incision. After exposing the stomach, $0.05 \mathrm{~mL}(\mathrm{v} / \mathrm{v})$ of a $100 \%$ acetic acid solution was pipetted onto a delimitated area (by plastic tube) at the serosal layer in the glandular part of the anterior wall. The stomach was bathed with saline to avoid adherence to the external surface of the ulcerated region. The abdomen was then closed and the animals were fed normally after recovering from surgery.

Rats were divided into groups: control (saline, $10 \mathrm{ml} / \mathrm{kg}$ ), lansoprazole (60 mg/kg) (Medley, Campinas, SP, Brazil) and HEAb $(300 \mathrm{mg} / \mathrm{kg}$ ). The animals received the treatments by gavage once a day for 7 or 14 consecutive days, beginning 2 days after surgery. During this period, body weight was recorded daily to evaluate possible toxicity induced by treatments. Five animals of each group were sacrificed at days 1, 7 and 14 after acetic acid-induction to evaluate the area of lesion. The stomachs were then photographed and the extent of the lesions was measured $\left(\mathrm{mm}^{2}\right)$ by the program AVSoft BioView 4.0 (AVSoft Softwares Laboratoriais, Campinas, SP, Brazil).

4.5.6.1. Toxicity evaluation. The toxicological parameters were set according to the method of Souza-Brito (1994), using the animals submitted to HEAb treatment under the aforementioned acetic acid model. For a period of 7 and 14 days, HEAb effects were observed daily (body weight progression, hair and mucosal alteration). The following organs were weighed to detect any effect of the extract on their individual organ-body weight ratios: heart, lungs, liver, kidneys and spleen data not shown.

4.5.6.2. Myeloperoxidase activity (MPO). MPO activity in the gastric mucosa was measured by the method proposed by (Krawisz et al., 1984), with minor modifications, to evaluate neutrophil accumulation. Briefly, the samples were centrifuged at $3000 \mathrm{~g}$ for $15 \mathrm{~min}$ at $4{ }^{\circ} \mathrm{C}$. Aliquots of the supernatant were then mixed with a reaction buffer of $50 \mathrm{mM}$ phosphate buffer, $\mathrm{pH} 6.8$, containing $0.005 \% \mathrm{H}_{2} \mathrm{O}_{2}$ and $1.25 \mathrm{mg} / \mathrm{ml} O$-dianisidine dihydrochloride, measurement was taken at $460 \mathrm{~nm}$. A standard curve of MPO (Sigma-Aldrich) was used to calculate the enzyme activity in the experimental samples; the MPO activity was expressed as $\mathrm{U} / \mathrm{mg}$ of protein.

4.5.6.3. Statistical analysis. Results are presented as mean \pm S.E.M. and the data were analysed by one-way analysis of variance (ANOVA) followed by Dunnett's or Tuckey's post hoc test; $p$ values less than 0.05 were considered significant. All statistical analyses were performed using GraphPad Prism 5.0 (GraphPad Software, San Diego, CA).

\subsection{Phytochemical evaluation}

\subsubsection{Computational methods}

Conformational analysis of $\mathbf{4}$ was performed with Schrödinger MacroModel 9.1 (Schrö dinger, LLC, New York) employing the OPLS2005 (optimized potential for liquid simulations) force field in $\mathrm{H}_{2} \mathrm{O}$. Conformers within a $2 \mathrm{kcaL} / \mathrm{mol}$ energy window from the global minimum were selected for geometrical optimization and energy calculation applying DFT with the B3LYP/6-31G** level of theory in the gas phase with the Gaussian 09 program package (Frisch et al., 2009). Vibrational evaluation was done at the same level to confirm minima. Excitation energy (denoted by wavelength in $\mathrm{nm})$, rotator strength dipole velocity $\left(R_{v e l}\right)$, and dipole length $\left(R_{\text {len }}\right)$ were calculated in MeOH by TDDFT/CAM-B3LYP/6-31G $\left.{ }^{* *}\right)$ in $\mathrm{MeOH}$ using the SCRF (self-consistent reaction field) method with the CPCM (conductor-like polarizable continuum) model. ECD curves were obtained on the basis of rotator strengths with a half-band of $0.25 \mathrm{eV}$ using SpecDis v1.61.(Bruhn et al., 2013).

\subsubsection{Isolation}

The dried roots (1000 g) were successively extracted by percolation at room temperature with EtOH- $\mathrm{H}_{2} \mathrm{O} 70 \%$. The crude ethanolic extract was obtained after filtration and evaporated to dryness under vacuum at approximately $40^{\circ} \mathrm{C}$, yielding $200.0 \mathrm{~g}$ of hydro-ethanolic extract. After extraction, further liquid/liquid extractions with the hydroethanolic extract were carried out using $\mathrm{CH}_{2} \mathrm{Cl}_{2}(1 \mathrm{~L})$ and $\mathrm{H}_{2} \mathrm{O}-\mathrm{MeOH}(7: 3)(1 \mathrm{~L})$. The crude $\mathrm{CH}_{2} \mathrm{Cl}_{2}$ and hydromethanolic fractions were obtained after decantation and evaporated to dryness under vacuum at approximately $40{ }^{\circ} \mathrm{C}$, yielding 35\% (69.6 g) and 65\% (130.4 g) of the dried fractions, respectively, based on the dry mass. The aqueous extract $(12.0 \mathrm{~g})$ was initially fractionated using MPLC with column packed with Zeoprep ${ }^{\circledR}$ C18 as stationary phase $(15-25 \mu \mathrm{m}, 460 \times 49 \mathrm{~mm}$ i.d.) (Zeochem, Uetikon am See, Switzerland); $\mathrm{MeOH}$ and $0.002 \%$ formic acid in water were added using a linear gradient from 10\% to $100 \%$ $\mathrm{MeOH}$ over $30 \mathrm{~h}$ period. The flow rate was $10 \mathrm{~mL} / \mathrm{min}$, and the UV absorbance was detected at $217 \mathrm{~nm}$. The MPLC generated $73 \mathrm{frac}-$ tions. Each fraction was analysed by HPLC-PDA. Fractions 8-10 (5.2 mg) yielded a mixture of compound 1 and 2, 24-25 (67 mg) yielded 3, fractions 41-46-1 (56.9 mg) yielded 5, 41-46-2 (49.0 mg) yielded 6, 50-52 (14.5 mg) yielded 7, 53-54 (34.9 mg) yielded 8, 55-57 (13.6 mg) yielded 9, 58-59 (76.9 mg) yielded 10.

\subsubsection{Compound characterization}

4.6.3.1. Mixture of compound 1 and 2. Amorphous white solid; (2(3,4-dihydroxyphenyl)ethyl 2-0-[5-0-(4-hydroxy-3,5dimethoxybenzoyl)-D-apio- $\beta$-D-furanosyl]- $\beta$-D-Glucopyrano-

side) (1): ${ }^{1} \mathrm{H}$ NMR (DMSO-d6, $\left.500 \mathrm{MHz}\right) \delta 6.54(1 \mathrm{H}, \mathrm{d}, J=2.0 \mathrm{~Hz}, \mathrm{H}-$ 2), $6.55(1 \mathrm{H}, \mathrm{d}, J=8.0 \mathrm{~Hz}, \mathrm{H}-5), 6.31(1 \mathrm{H}, \mathrm{dd}, J=8.0,2.0 \mathrm{~Hz}, \mathrm{H}-6)$, $2.56(1 \mathrm{H}, \mathrm{t}, J=7.8 \mathrm{~Hz}, \mathrm{H}-7), 3.38(1 \mathrm{H}, \mathrm{m}, \mathrm{H}-8 \mathrm{~b}), 3.78(1 \mathrm{H}, \mathrm{m}, \mathrm{H}-8 \mathrm{a})$, $4.19\left(1 \mathrm{H}, \mathrm{d}, J=8.0 \mathrm{~Hz}, \mathrm{H}-1^{\prime}\right), 3.24\left(1 \mathrm{H}, \mathrm{t}, J=8.0 \mathrm{~Hz}, \mathrm{H}-2^{\prime}\right), 3.32(1 \mathrm{H}, \mathrm{t}$, $\left.J=8.0 \mathrm{~Hz}, \mathrm{H}-3^{\prime}\right), 3.06\left(2 \mathrm{H}, \mathrm{m}, \mathrm{H}-4^{\prime}, 5^{\prime}\right), 3.41(1 \mathrm{H}, \mathrm{dd}, J=12.5,4.3 \mathrm{~Hz}$, H-6'b), $3.63(1 \mathrm{H}, \mathrm{t}, J=12.5 \mathrm{~Hz}, \mathrm{H}-6 \mathrm{\prime} \mathrm{a}), 5.36\left(1 \mathrm{H}, \mathrm{s}, \mathrm{H}-1^{\prime \prime}\right), 3.85(1 \mathrm{H}, \mathrm{s}$, $\left.\mathrm{H}-2^{\prime \prime}\right), 3.73\left(1 \mathrm{H}, \mathrm{d}, J=9.4 \mathrm{~Hz}, 4^{\prime \prime} \mathrm{b}\right), 4.07\left(1 \mathrm{H}, \mathrm{d}, J=9.4 \mathrm{~Hz}, \mathrm{H}-4^{\prime \prime} \mathrm{a}\right)$, 4.25 ( $\left.1 \mathrm{H}, \mathrm{d}, J=11.1 \mathrm{~Hz}, \mathrm{H}-5^{\prime \prime} \mathrm{b}\right), 4.39$ (1H, d, J=11.1 Hz, H-5"a), 7.25 $\left(2 \mathrm{H}, \mathrm{s}, \mathrm{H}-2^{\prime \prime \prime}, 6^{\prime \prime \prime}\right), 3.78\left(6 \mathrm{H}, \mathrm{s}, 3^{\prime \prime \prime}-\mathrm{OCH}_{3}, 5^{\prime \prime \prime}-\mathrm{OCH}_{3}\right) ;{ }^{13} \mathrm{C}$ NMR (DMSO-d6, $126 \mathrm{MHz}$ ) $\delta 128.9$ (C-1), 116.2 (C-2), 144.9 (C-3), 143.5 (C-4), 115.3 (C-5), 119.3 (C-6), $35.0(\mathrm{C}-7), 69.9(\mathrm{C}-8), 101.1\left(\mathrm{C}-1^{\prime}\right), 75.5$ (C-2'), $77.3\left(\mathrm{C}-3^{\prime}\right), 70.3\left(\mathrm{C}-4^{\prime}\right), 76.7\left(\mathrm{C}-5^{\prime}\right), 60.9\left(\mathrm{C}-6^{\prime}\right), 108.1\left(\mathrm{C}-1^{\prime \prime}\right)$, $76.6\left(\mathrm{C}-2^{\prime \prime}\right), 77.5\left(\mathrm{C}-3^{\prime \prime}\right), 73.8\left(\mathrm{C}-4^{\prime \prime}\right), 67.6\left(\mathrm{C}-5^{\prime \prime}\right), 119.3\left(\mathrm{C}-1^{\prime \prime \prime}\right), 107.3$ (C-2'" $\left.6^{\prime \prime \prime}\right), 147.5$ (C-3'" $\left.5^{\prime \prime \prime}\right), 140.9\left(\mathrm{C}-4^{\prime \prime \prime}\right), 165.5\left(\mathrm{C}-7^{\prime \prime \prime}\right), 56.1$ $\left(3^{\prime \prime \prime}-\mathrm{OCH}_{3}, 5^{\prime \prime \prime}-\mathrm{OCH}_{3}\right)$; ESI-MS/MS (Neg. Mod.): m/z: $627[\mathrm{M}-\mathrm{H}]^{-}$, 597, 429; HRMS (Neg. Mod.): $m / z 627.1923$ [M-H] $^{-}$(calcd for $\left.\mathrm{C}_{28} \mathrm{H}_{35} \mathrm{O}_{16}, 627.1925, \Delta=-0.3 \mathrm{ppm}\right)$; (2-(3,4-dihydroxyphenyl) 
ethyl 2-0-[5-0-(3,4-dihydroxybenzoyl)-D-apio- $\beta$-D-furanosyl]$\boldsymbol{\beta}$-D-Glucopyranoside) (2): ${ }^{1} \mathrm{H}$ NMR (DMSO-d6, $\left.500 \mathrm{MHz}\right) \delta 6.54$ $(1 \mathrm{H}, \mathrm{d}, J=2.0 \mathrm{~Hz}, \mathrm{H}-2), 6.55(1 \mathrm{H}, \mathrm{d}, J=8.0 \mathrm{~Hz}, \mathrm{H}-5), 6.31(1 \mathrm{H}, \mathrm{dd}$, $J=8.0,2.0 \mathrm{~Hz}, \mathrm{H}-6), 2.56(1 \mathrm{H}, \mathrm{t}, J=7.8 \mathrm{~Hz}, \mathrm{H}-7), 3.38(1 \mathrm{H}, \mathrm{m}, \mathrm{H}-8 \mathrm{~b})$, $3.78(1 \mathrm{H}, \mathrm{m}, \mathrm{H}-8 \mathrm{a}), 4.20\left(1 \mathrm{H}, \mathrm{d}, J=8.0 \mathrm{~Hz}, \mathrm{H}-1^{\prime}\right), 3.24(1 \mathrm{H}, \mathrm{t}$, $\left.J=8.0 \mathrm{~Hz}, \mathrm{H}-2^{\prime}\right), 3.32\left(1 \mathrm{H}, \mathrm{t}, J=8.0 \mathrm{~Hz}, \mathrm{H}-3^{\prime}\right), 3.06\left(2 \mathrm{H}, \mathrm{m}, \mathrm{H}-4^{\prime}, 5^{\prime}\right)$, $3.41(1 \mathrm{H}, \mathrm{m}, \mathrm{H}-6 \mathrm{\prime}$ ) $), 3.63(1 \mathrm{H}, \mathrm{t}, J=12.2 \mathrm{~Hz}, \mathrm{H}-6 \mathrm{a}), 5.35\left(1 \mathrm{H}, \mathrm{s}, \mathrm{H}-1^{\prime \prime}\right)$, $3.84\left(1 \mathrm{H}, \mathrm{s}, \mathrm{H}-2^{\prime \prime}\right), 3.71\left(1 \mathrm{H}, \mathrm{d}, J=9.4 \mathrm{~Hz}, \mathrm{H}-4^{\prime \prime} \mathrm{b}\right), 4.06(1 \mathrm{H}, \mathrm{d}$, $\left.J=9.4 \mathrm{~Hz}, \mathrm{H}-4^{\prime \prime} \mathrm{a}\right), 4.25$ (1H, d, $\left.J=11.2 \mathrm{~Hz}, \mathrm{H}-5^{\prime \prime} \mathrm{b}\right), 4.34(1 \mathrm{H}, \mathrm{d}$, $\left.J=11.2 \mathrm{~Hz}, 5^{\prime \prime} \mathrm{a}\right), 7.46\left(1 \mathrm{H}, \mathrm{d}, J=1.8 \mathrm{~Hz}, \mathrm{H}-2^{\prime \prime \prime}\right), 6.86(1 \mathrm{H}, \mathrm{d}, J=8.3 \mathrm{~Hz}$, $\left.\mathrm{H}-5^{\prime \prime \prime}\right), 7.52\left(1 \mathrm{H}\right.$, dd, $\left.J=8.3,1.8 \mathrm{~Hz}, \mathrm{H}-6^{\prime \prime \prime}\right) ;{ }^{13} \mathrm{C}$ NMR (DMSO-d6, $126 \mathrm{MHz}$ ) $\delta 128.9$ (C-1), 116.2 (C-2), 144.9 (C-3), 143.5 (C-4), 115.3 (C-5), 119.3 (C-6), $35.0(\mathrm{C}-7), 69.9(\mathrm{C}-8), 101.1\left(\mathrm{C}-1^{\prime}\right), 75.5\left(\mathrm{C}-2^{\prime}\right), 77.3$ $\left(\mathrm{C}-3^{\prime}\right), 70.3\left(\mathrm{C}-4^{\prime}\right), 76.7\left(\mathrm{C}-5^{\prime}\right), 60.9\left(\mathrm{C}-6^{\prime}\right), 108.1\left(\mathrm{C}-1^{\prime \prime}\right), 76.6\left(\mathrm{C}-2^{\prime \prime}\right)$, $77.5\left(\mathrm{C}-3^{\prime \prime}\right), 73.8\left(\mathrm{C}-4^{\prime \prime}\right), 67.3\left(\mathrm{C}-5^{\prime \prime}\right), 120.5\left(\mathrm{C}-1^{\prime \prime \prime}\right), 112.9\left(\mathrm{C}-2^{\prime \prime \prime}\right), 147.5$

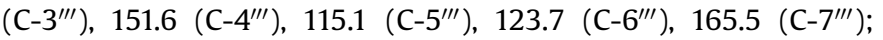
ESIMS/MS (NI): $m / z 583.1[\mathrm{M}-\mathrm{H}]^{-}, 429.1[\mathrm{M}-\mathrm{H}]^{-}$; HRMS (NI): $m / z$ 583. $1670[\mathrm{M}-\mathrm{H}]^{-}$(calcd for $\mathrm{C}_{26} \mathrm{H}_{31} \mathrm{O}_{15}, 583.1657$ ).

4.6.3.2. Brachydin $D$ (3). Amorphous white solid; $[\alpha]_{D}^{20}-6,5^{\circ}$ (c 0.1 $\mathrm{MeOH}) ; \mathrm{UV} \lambda_{\max }(\log \varepsilon) 267 \mathrm{~nm}$ (4.57); ECD (MeOH, c $0.1 \mathrm{mM}$, $0.1 \mathrm{~cm})[\theta]_{215}=-59671,[\theta]_{225}=-22393 ;{ }^{1} \mathrm{H}$ NMR $\left(\mathrm{CD}_{3} \mathrm{OD}\right.$, $500 \mathrm{MHz}) \delta 6.39(1 \mathrm{H}, \mathrm{d}, J=2.1 \mathrm{~Hz}, \mathrm{H}-2), 6.25(1 \mathrm{H}, \mathrm{d}, J=2.1 \mathrm{~Hz}, \mathrm{H}-4)$, $4.75(1 \mathrm{H}, \mathrm{d}, J=11.3 \mathrm{~Hz}, \mathrm{H}-6), 2.26(1 \mathrm{H}, \mathrm{ddd}, J=11.3,5.1,2.4 \mathrm{~Hz}, \mathrm{H}-$ 6a), 3.20 ( $1 \mathrm{H}, \mathrm{d}, J=5.1 \mathrm{~Hz}, \mathrm{H}-7), 6.35(1 \mathrm{H}, \mathrm{d}, J=2.1 \mathrm{~Hz}, \mathrm{H}-9), 6.29$ $(1 \mathrm{H}, \mathrm{d}, J=2.1 \mathrm{~Hz}, \mathrm{H}-11), 5.32(1 \mathrm{H}, \mathrm{d}, J=2.4 \mathrm{~Hz}, \mathrm{H}-12 \mathrm{a}), 7.24(2 \mathrm{H}, \mathrm{m}$, $\left.\mathrm{H}-2^{\prime}, 6^{\prime}\right), 7.38\left(3 \mathrm{H}, \mathrm{m}, \mathrm{H}-3^{\prime}, 4^{\prime}, 5^{\prime}\right), 5.96(1 \mathrm{H}, \mathrm{dd}, J=15.8,5.1 \mathrm{~Hz}, \mathrm{H}-\alpha)$, $5.79(1 \mathrm{H}, \mathrm{dd}, J=15.8,1.3 \mathrm{~Hz}, \mathrm{H}-\beta), 7.05\left(2 \mathrm{H}, \mathrm{d}, J=8.3 \mathrm{~Hz}, \mathrm{H}-2^{\prime \prime}, 6^{\prime \prime}\right)$, $6.64\left(2 \mathrm{H}, \mathrm{d}, J=8.3 \mathrm{~Hz}, \mathrm{H}-3^{\prime \prime}, 5^{\prime \prime}\right), 3.83$ (3H, s, 1-OMe), 3.65 (3H, s, 8OMe), 3-GlcA: $4.94\left(1 \mathrm{H}, \mathrm{d}, J=6.5 \mathrm{~Hz}, \mathrm{H}-1^{\prime}\right), 3.50\left(2 \mathrm{H}, \mathrm{m}, \mathrm{H}-2^{\prime}, 3^{\prime}\right)$, $3.60\left(1 \mathrm{H}, \mathrm{m}, \mathrm{H}-4^{\prime}\right), 3.94\left(1 \mathrm{H}, \mathrm{d}, J=9.6 \mathrm{~Hz}, \mathrm{H}-5^{\prime}\right), 10-\mathrm{GlcA}: 4.99(1 \mathrm{H}, \mathrm{d}$, $\left.J=7.1 \mathrm{~Hz}, \mathrm{H}-1^{\prime}\right), 3.52\left(2 \mathrm{H}, \mathrm{m}, \mathrm{H}-2^{\prime}, 3^{\prime}\right), 3.62\left(1 \mathrm{H}, \mathrm{m}, \mathrm{H}-4^{\prime}\right), 4.01(1 \mathrm{H}$, $\left.\mathrm{d}, J=9.6 \mathrm{~Hz}, \mathrm{H}-5^{\prime}\right) .{ }^{13} \mathrm{C}$ NMR $\left(\mathrm{CD}_{3} \mathrm{OD}, 126 \mathrm{MHz}\right) \delta 160.5(\mathrm{C}-1), 94.1$ (C-2), 160.8 (C-3), 97.8 (C-4), 157.3 (C-4a), 78.0 (C-6), 41.7 (C-6a), 33.7 (C-7), 104.4 (C-7a), 159.7 (C-8), 94.3 (C-9), 159.2 (C-10), 97.6 (C11), 154.8 (C-11a), 63.3 (C-12a), 106.2 (C-12b), $139.8\left(\mathrm{C}-1^{\prime}\right), 128.3$ (C$\left.2^{\prime}, 6^{\prime}\right), 129.3\left(\mathrm{C}-3^{\prime}, 4^{\prime}, 5^{\prime}\right), 129.3(\mathrm{C}-\alpha), 131.7(\mathrm{C}-\beta), 129.9\left(\mathrm{C}-1^{\prime \prime}\right), 128.2$ $\left(\mathrm{C}-2^{\prime \prime}, 6^{\prime \prime}\right), 116.0\left(\mathrm{C}-3^{\prime \prime}, 5^{\prime \prime}\right), 157.5\left(\mathrm{C}-4^{\prime \prime}\right), 56.0(1-\mathrm{OMe}), 55.9(8-\mathrm{OMe})$, 3-GlcA: $101.9\left(\mathrm{C}-1^{\prime}\right), 74.3\left(\mathrm{C}-2^{\prime}\right), 77.0\left(\mathrm{C}-3^{\prime}\right), 72.7\left(\mathrm{C}-4^{\prime}\right), 76.2\left(\mathrm{C}-5^{\prime}\right)$, 172.0 (C-6'), 10-GlcA: 102.1 (C-1'), $74.3\left(\mathrm{C}-2^{\prime}\right), 77.1\left(\mathrm{C}-3^{\prime}\right), 72.7\left(\mathrm{C}-4^{\prime}\right)$, $76.2\left({\mathrm{C}-5^{\prime}}^{\prime}\right), 172.1$ (C-6'); ESIMS/MS (PI): $m / z 877$ [M+H] ${ }^{+}, 700$ [M$177]^{+}, 447,271$; HRMS (NI): $m / z 875.2426$ [M-H] $^{-}$(calcd for $\left.\mathrm{C}_{44} \mathrm{H}_{43} \mathrm{O}_{19}, 875.2399, \Delta=3.1 \mathrm{ppm}\right)$.

4.6.3.3. Brachydin $E$ (5). Amorphous white solid; $[\alpha]_{D}^{20}-8,2^{\circ}$ (c 0.1 $\mathrm{MeOH}) ; \mathrm{UV} \lambda_{\max }(\log \varepsilon) 265 \mathrm{~nm}(4.84) ;{ }^{1} \mathrm{H}$ NMR $\left(\mathrm{CD}_{3} \mathrm{OD}, 500 \mathrm{MHz}\right)$ $\delta 6.41(1 \mathrm{H}, \mathrm{d}, J=2.2 \mathrm{~Hz}, \mathrm{H}-2), 6.28(1 \mathrm{H}, \mathrm{d}, J=2.2 \mathrm{~Hz}, \mathrm{H}-4), 4.79(1 \mathrm{H}$, $\mathrm{d}, J=11.3 \mathrm{~Hz}, \mathrm{H}-6), 2.36$ (1H, dd, $J=11.3,2.6 \mathrm{~Hz}, \mathrm{H}-6 \mathrm{a}), 3.26$ (1H, d, $J=5.5 \mathrm{~Hz}, \mathrm{H}-7), 6.38(1 \mathrm{H}, \mathrm{d}, J=2.1 \mathrm{~Hz}, \mathrm{H}-9), 6.30(1 \mathrm{H}, \mathrm{d}, J=2.1 \mathrm{~Hz}$, $\mathrm{H}-11), 5.34(1 \mathrm{H}, \mathrm{d}, J=2.6 \mathrm{~Hz}, \mathrm{H}-12 \mathrm{a}), 7.25\left(2 \mathrm{H}, \mathrm{m}, \mathrm{H}-2^{\prime}, 6^{\prime}\right), 7.39(3 \mathrm{H}$, $\left.\mathrm{m}, \mathrm{H}-3^{\prime}, 4^{\prime}, 5^{\prime}\right), 6.21(1 \mathrm{H}, \mathrm{dd}, J=15.8,5.5 \mathrm{~Hz}, \mathrm{H}-\alpha), 5.91(1 \mathrm{H}, \mathrm{d}$, $J=15.8 \mathrm{~Hz}, \mathrm{H}-\beta), 7.23\left(2 \mathrm{H}, \mathrm{m}, \mathrm{H}-2^{\prime \prime}, 6^{\prime \prime}\right), 7.22\left(2 \mathrm{H}, \mathrm{m}, \mathrm{H}-3^{\prime \prime}, 5^{\prime \prime}\right), 7.13$ $\left(1 \mathrm{H}, \mathrm{t}, J=7.0 \mathrm{~Hz}, \mathrm{H}-4^{\prime \prime}\right), 3.85$ (3H, s, 1-OMe), 3.67 (3H, s, 8-OMe), 3GlcA: $4.94\left(1 \mathrm{H}, \mathrm{d}, J=6.9 \mathrm{~Hz}, \mathrm{H}-1^{\prime}\right), 3.49\left(1 \mathrm{H}, \mathrm{m}, \mathrm{H}-2^{\prime}\right), 3.50(1 \mathrm{H}, \mathrm{m}$, $\left.\mathrm{H}-3^{\prime}\right), 3.55\left(1 \mathrm{H}, \mathrm{m}, \mathrm{H}-4^{\prime}\right), 3.82\left(1 \mathrm{H}, \mathrm{d}, J=7.6 \mathrm{~Hz}, \mathrm{H}-5^{\prime}\right), 10-\mathrm{GlcA}: 4.97$ $\left(1 \mathrm{H}, \mathrm{d}, J=7.0 \mathrm{~Hz}, \mathrm{H}-1^{\prime}\right), 3.52\left(2 \mathrm{H}, \mathrm{m}, \mathrm{H}-2^{\prime}, 3^{\prime}\right), 3.55\left(1 \mathrm{H}, \mathrm{m}, \mathrm{H}-4^{\prime}\right)$, $3.87\left(1 \mathrm{H}, \mathrm{d}, J=7.6 \mathrm{~Hz}, \mathrm{H}-5^{\prime}\right) ;{ }^{13} \mathrm{C} \mathrm{NMR}\left(\mathrm{CD}_{3} \mathrm{OD}, 126 \mathrm{MHz}\right) \delta 160.5(\mathrm{C}-$ 1), 94.2 (C-2), 160.8 (C-3), 97.8 (C-4), 157.3 (C-4a), 77.9 (C-6), 41.5 (C6a), 33.7 (C-7), 103.6 (C-7a), 159.7 (C-8), 94.2 (C-9), 159.2 (C-10), 97.8 (C-11), 154.8 (C-11a), 63.2 (C-12a), 105.9 (C-12b), $139.6\left(\mathrm{C}-1^{\prime}\right)$, 128.2 (C-2', 6'), $129.3\left(\mathrm{C}-3^{\prime}, 4^{\prime}, 5^{\prime}\right), 133.0(\mathrm{C}-\alpha), 132.0(\mathrm{C}-\beta), 138.0(\mathrm{C}-$ $\left.1^{\prime \prime}\right), 126.9\left(\mathrm{C}-2^{\prime \prime}, 6^{\prime \prime}\right), 129.1\left(\mathrm{C}-3^{\prime \prime}, 5^{\prime \prime}\right), 127.8$ (C-4" $), 56.0$ (1-OMe), 55.8 (8-OMe), 3-GlcA: $101.9\left(\mathrm{C}-1^{\prime}\right), 74.3\left(\mathrm{C}-2^{\prime}\right), 77.3\left(\mathrm{C}-3^{\prime}\right), 73.0(\mathrm{C}-$ $\left.4^{\prime}\right), 76.2\left(\mathrm{C}-5^{\prime}\right), 10-\mathrm{GlcA}: 102.0\left(\mathrm{C}-1^{\prime}\right), 74.3\left(\mathrm{C}-2^{\prime}\right), 77.4\left(\mathrm{C}-3^{\prime}\right), 73.0(\mathrm{C}-$

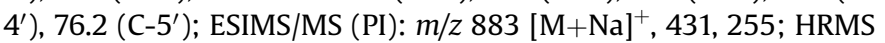

(NI): $m / z \quad 859.2457[\mathrm{M}-\mathrm{H}]^{-}$(calcd for $\mathrm{C}_{44} \mathrm{H}_{43} \mathrm{O}_{18}, 859.2449$, $\Delta=1.0 \mathrm{ppm})$.

4.6.3.4. Brachydin $F(6)$. Amorphous white solid; $[\alpha]_{\mathrm{D}}^{20}-8,0^{\circ}$ (c 0.1 $\mathrm{MeOH}) ; \mathrm{UV} \lambda_{\max }(\log \varepsilon) 275 \mathrm{~nm}$ (5.94); ECD (MeOH, c $0.1 \mathrm{mM}$, $0.1 \mathrm{~cm})[\theta]_{215}=-252293,[\theta]_{225}=-105020 ;{ }^{1} \mathrm{H}$ NMR $\left(\mathrm{CD}_{3} \mathrm{OD}\right.$, $500 \mathrm{MHz}) \delta 6.40(1 \mathrm{H}, \mathrm{d}, J=2.1 \mathrm{~Hz}, \mathrm{H}-2), 6.26(1 \mathrm{H}, \mathrm{d}, J=2.1 \mathrm{~Hz}, \mathrm{H}-4)$, $4.77(1 \mathrm{H}, \mathrm{d}, J=11.3 \mathrm{~Hz}, \mathrm{H}-6), 2.26(1 \mathrm{H}, \mathrm{dd}, J=11.3,2.4 \mathrm{~Hz}, \mathrm{H}-6 \mathrm{a})$, $3.23(1 \mathrm{H}, \mathrm{d}, J=5.5 \mathrm{~Hz}, \mathrm{H}-7), 6.36(1 \mathrm{H}, \mathrm{d}, J=2.1 \mathrm{~Hz}, \mathrm{H}-9), 6.29(1 \mathrm{H}, \mathrm{d}$, $J=2.1 \mathrm{~Hz}, \mathrm{H}-11), 5.32(1 \mathrm{H}, \mathrm{d}, J=2.4 \mathrm{~Hz}, \mathrm{H}-12 \mathrm{a}), 7.24\left(2 \mathrm{H}, \mathrm{m}, \mathrm{H}-2^{\prime}\right.$, $\left.6^{\prime}\right), 7.39\left(3 \mathrm{H}, \mathrm{m}, \mathrm{H}-3^{\prime}, 4^{\prime}, 5^{\prime}\right), 6.02(1 \mathrm{H}, \mathrm{dd}, J=15.8,5.5 \mathrm{~Hz}, \mathrm{H}-\alpha), 5.83$ $(1 \mathrm{H}, \mathrm{d}, J=15.8 \mathrm{~Hz}, \mathrm{H}-\beta), 7.15\left(2 \mathrm{H}, \mathrm{d}, J=8.8 \mathrm{~Hz}, \mathrm{H}-2^{\prime \prime}, 6^{\prime \prime}\right), 6.77(2 \mathrm{H}, \mathrm{d}$, $J=8.8 \mathrm{~Hz}, \mathrm{H}-3^{\prime \prime}, 5^{\prime \prime}$ ), 3.84 (3H, s, 1-OMe), 3.66 (3H, s, 8-OMe), 3.74 (3H, s, 4"-OMe), 3-GlcA: $4.94\left(1 \mathrm{H}, \mathrm{d}, J=6.0 \mathrm{~Hz}, \mathrm{H}-1^{\prime}\right), 3.53(2 \mathrm{H}, \mathrm{m}$, $\left.\mathrm{H}-2^{\prime}, 3^{\prime}\right), 3.59\left(1 \mathrm{H}, \mathrm{m}, \mathrm{H}-4^{\prime}\right), 3.89\left(1 \mathrm{H}, \mathrm{d}, J=9.5 \mathrm{~Hz}, \mathrm{H}-5^{\prime}\right), 10-\mathrm{GlcA}$ : $4.98\left(1 \mathrm{H}, \mathrm{d}, J=7.0 \mathrm{~Hz}, \mathrm{H}-1^{\prime}\right), 3.52\left(2 \mathrm{H}, \mathrm{m}, \mathrm{H}-2^{\prime}, 3^{\prime}\right), 3.62(1 \mathrm{H}, \mathrm{m}, \mathrm{H}-$ $\left.4^{\prime}\right), 3.95\left(1 \mathrm{H}, \mathrm{d}, J=9.6 \mathrm{~Hz}, \mathrm{H}-5^{\prime}\right) .{ }^{13} \mathrm{C} \mathrm{NMR}\left(\mathrm{CD}_{3} \mathrm{OD}, 126 \mathrm{MHz}\right) \delta 160.5$ (C-1), 94.1 (C-2), 160.8 (C-3), 97.8 (C-4), 157.3 (C-4a), 77.9 (C-6), 41.7 (C-6a), 33.7 (C-7), 104.4 (C-7a), 159.7 (C-8), 94.3 (C-9), 159.2 (C-10), 97.6 (C-11), 154.8 (C-11a), 63.2 (C-12a), 106.2 (C-12b), $139.8\left(\mathrm{C}-1^{\prime}\right)$, $128.3\left(\mathrm{C}-2^{\prime}, 6^{\prime}\right), 129.3\left(\mathrm{C}-3^{\prime}, 4^{\prime}, 5^{\prime}\right), 130.7(\mathrm{C}-\alpha), 131.4(\mathrm{C}-\beta), 129.9(\mathrm{C}-$

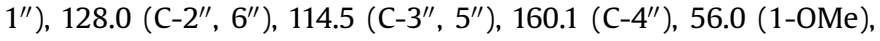
55.8 (8-OMe), 55.3 (4"-OMe), 3-GlcA: $101.9\left(\mathrm{C}-1^{\prime}\right), 74.3$ (C-2'), 77.0 (C-3'), $72.7\left(\mathrm{C}-4^{\prime}\right), 76.2\left(\mathrm{C}-5^{\prime}\right), 10-G l c A: 102.0\left(\mathrm{C}-1^{\prime}\right), 74.3\left(\mathrm{C}-2^{\prime}\right), 77.1$ (C-3'), 72.7 (C-4'), $76.2\left(\right.$ C-5' $^{\prime}$ ); ESIMS/MS (PI): m/z $913[\mathrm{M}+\mathrm{Na}]^{+}$, 461, 285; HRMS (NI): $m / z$ 889.2586 [M-H] ${ }^{-}$(calcd for $\mathrm{C}_{45} \mathrm{H}_{45} \mathrm{O}_{19}$, 889.2555, $\Delta=5.7 \mathrm{ppm})$.

4.6.3.5. Brachydin $G(7)$. Amorphous white solid; $[\alpha]_{\mathrm{D}}^{20}-11,2^{\circ}$ (c 0.1 $\mathrm{MeOH}) ; \mathrm{UV} \lambda_{\max }(\log \varepsilon) 259 \mathrm{~nm}$ (4.69); ECD (MeOH, c $0.1 \mathrm{mM}$, $0.1 \mathrm{~cm})[\theta]_{215}=-219625,[\theta]_{225}=-88375 ;{ }^{1} \mathrm{H}$ NMR (DMSO-d6, $500 \mathrm{MHz}) \delta 6.32(1 \mathrm{H}, \mathrm{d}, J=2.1 \mathrm{~Hz}, \mathrm{H}-2), 6.18(1 \mathrm{H}, \mathrm{d}, J=2.1 \mathrm{~Hz}, \mathrm{H}-4)$, $4.74(1 \mathrm{H}, \mathrm{d}, J=11.3 \mathrm{~Hz}, \mathrm{H}-6), 2.46(1 \mathrm{H}, \mathrm{ddd}, J=11.3,5.1,2.4 \mathrm{~Hz}, \mathrm{H}-$ 6a), 3.09 (1H, d, $J=5.1 \mathrm{~Hz}, \mathrm{H}-7), 6.01(1 \mathrm{H}, \mathrm{d}, J=2.1 \mathrm{~Hz}, \mathrm{H}-9), 5.87$ $(1 \mathrm{H}, \mathrm{d}, J=2.1 \mathrm{~Hz}, \mathrm{H}-11), 5.18(1 \mathrm{H}, \mathrm{d}, J=2.4 \mathrm{~Hz}, \mathrm{H}-12 \mathrm{a}), 7.27(2 \mathrm{H}, \mathrm{m}$, $\left.\mathrm{H}-2^{\prime}, 6^{\prime}\right), 7.41\left(3 \mathrm{H}, \mathrm{m}, \mathrm{H}-3^{\prime}, 4^{\prime}, 5^{\prime}\right), 6.06(1 \mathrm{H}, \mathrm{dd}, J=15.8,5.1 \mathrm{~Hz}, \mathrm{H}-\alpha)$, $5.75(1 \mathrm{H}, \mathrm{d}, J=15.8 \mathrm{~Hz}, \mathrm{H}-\beta), 7.11\left(2 \mathrm{H}, \mathrm{d}, J=8.7 \mathrm{~Hz}, \mathrm{H}-2^{\prime \prime}, 6^{\prime \prime}\right), 6.63$ $\left(2 \mathrm{H}, \mathrm{d}, J=8.7 \mathrm{~Hz}, \mathrm{H}-3^{\prime \prime}, 5^{\prime \prime}\right), 3.79$ (3H, s, 1-OMe), 3.56 (3H, s, 8-OMe), 3-GlcA: $4.86\left(1 \mathrm{H}, \mathrm{d}, J=7.7 \mathrm{~Hz}, \mathrm{H}-1^{\prime}\right), 3.19\left(1 \mathrm{H}, \mathrm{m}, \mathrm{H}-2^{\prime}\right), 3.24(1 \mathrm{H}, \mathrm{m}$, $\left.\mathrm{H}-3^{\prime}\right), 3.18\left(1 \mathrm{H}, \mathrm{m}, \mathrm{H}-4^{\prime}\right), 3.48\left(1 \mathrm{H}, \mathrm{d}, J=9.0 \mathrm{~Hz}, \mathrm{H}-5^{\prime}\right) .{ }^{13} \mathrm{C}$ NMR (DMSO-d6, $126 \mathrm{MHz}$ ) \& 158.9 (C-1), 93.4 (C-2), 159.8 (C-3), 96.2 (C4), 155.7 (C-4a), 76.5 (C-6), 39.2 (C-6a), 32.3 (C-7), 99.5 (C-7a), 158.5 (C-8), 92.3 (C-9), 157.7 (C-10), 95.4 (C-11), 153.4 (C-11a), 61.5 (C12a), 104.2 (C-12b), $138.4\left(\mathrm{C}-1^{\prime}\right), 127.7\left(\mathrm{C}-2^{\prime}, 6^{\prime}\right), 128.6\left(\mathrm{C}-3^{\prime}, 5^{\prime}\right)$, $129.7\left(\mathrm{C}-4^{\prime}\right), 128.8(\mathrm{C}-\alpha), 129.6(\mathrm{C}-\beta), 127.9\left(\mathrm{C}-1^{\prime \prime}\right), 127.4\left(\mathrm{C}-2^{\prime \prime}, 6^{\prime \prime}\right)$, 115.3 (C-3", $\left.5^{\prime \prime}\right), 156.7\left(\mathrm{C}-4^{\prime \prime}\right), 55.7$ (1-OMe), 55.4 (8-OMe), 3-GlcA: $100.3\left(\mathrm{C}-1^{\prime}\right), 73.7\left(\mathrm{C}-2^{\prime}\right), 76.5\left(\mathrm{C}-3^{\prime}\right), 72.1\left(\mathrm{C}-4^{\prime}\right), 73.9\left(\mathrm{C}-5^{\prime}\right), 171.9(\mathrm{C}-$ $\left.6^{\prime}\right)$; ESIMS/MS (PI): $m / z 723$ [M+Na] $]^{+}, 431,271$; HRMS (NI): $m / z$ $699.2072[\mathrm{M}-\mathrm{H}]^{-}$(calcd for $\left.\mathrm{C}_{38} \mathrm{H}_{35} \mathrm{O}_{13}, 699.2078, \Delta=-0.9 \mathrm{ppm}\right)$.

4.6.3.6. Brachydin $H(\boldsymbol{8})$. Amorphous white solid; $[\alpha]_{\mathrm{D}}^{20}-10,0^{\circ}$ (c 0.1 $\mathrm{MeOH}) ; \mathrm{UV} \lambda_{\max }(\log \varepsilon) 264 \mathrm{~nm}(5.75) ;{ }^{1} \mathrm{H} \mathrm{NMR}\left(\mathrm{CD}_{3} \mathrm{OD}, 500 \mathrm{MHz}\right)$ $\delta 6.09(1 \mathrm{H}, \mathrm{d}, J=2.1 \mathrm{~Hz}, \mathrm{H}-2), 5.94(1 \mathrm{H}, \mathrm{d}, J=2.1 \mathrm{~Hz}, \mathrm{H}-4), 4.77(1 \mathrm{H}$, $\mathrm{d}, J=11.3 \mathrm{~Hz}, \mathrm{H}-6), 2.29(1 \mathrm{H}, \mathrm{dt}, J=11.3,2.0 \mathrm{~Hz}, \mathrm{H}-6 \mathrm{a}), 3.22(1 \mathrm{H}, \mathrm{dt}$, $J=5.6,2.0 \mathrm{~Hz}, \mathrm{H}-7), 6.36(1 \mathrm{H}, \mathrm{d}, J=2.3 \mathrm{~Hz}, \mathrm{H}-9), 6.29(1 \mathrm{H}, \mathrm{d}$, $J=2.3 \mathrm{~Hz}, \mathrm{H}-11), 5.32(1 \mathrm{H}, \mathrm{d}, J=2.0 \mathrm{~Hz}, \mathrm{H}-12 \mathrm{a}), 7.24\left(2 \mathrm{H}, \mathrm{m}, \mathrm{H}-2^{\prime}\right.$, $\left.6^{\prime}\right), 7.39\left(3 \mathrm{H}, \mathrm{m}, \mathrm{H}-3^{\prime}, 4^{\prime}, 5^{\prime}\right), 5.99$ ( $\left.1 \mathrm{H}, \mathrm{dd}, J=15.8,5.6 \mathrm{~Hz}, \mathrm{H}-\alpha\right), 5.80$ $(1 \mathrm{H}, \mathrm{dd}, J=15.8,2.0 \mathrm{~Hz}, \mathrm{H}-\beta), 7.07\left(2 \mathrm{H}, \mathrm{d}, J=8.7 \mathrm{~Hz}, \mathrm{H}-2^{\prime \prime}, 6^{\prime \prime}\right), 6.65$ $\left(2 \mathrm{H}, \mathrm{d}, J=8.7 \mathrm{~Hz}, \mathrm{H}-3^{\prime \prime}, 5^{\prime \prime}\right), 3.82$ (3H, s, 1-OMe), 3.66 (3H, s, 8-OMe), 10-GlcA: $4.99\left(1 \mathrm{H}, \mathrm{d}, J=7.5 \mathrm{~Hz}, \mathrm{H}-1^{\prime}\right), 3.50\left(1 \mathrm{H}, \mathrm{m}, \mathrm{H}-2^{\prime}\right), 3.52(1 \mathrm{H}$, $\left.\mathrm{m}, \mathrm{H}-3^{\prime}\right), 3.61\left(1 \mathrm{H}, \mathrm{dd}, J=9.7,7.3 \mathrm{~Hz}, \mathrm{H}-4^{\prime}\right), 3.98(1 \mathrm{H}, \mathrm{d}, J=9.7 \mathrm{~Hz}, \mathrm{H}-$ $\left.5^{\prime}\right) .{ }^{13} \mathrm{C}$ NMR $\left(\mathrm{CD}_{3} \mathrm{OD}, 126 \mathrm{MHz}\right) \delta 161.0(\mathrm{C}-1), 92.8(\mathrm{C}-2), 161.1(\mathrm{C}-3)$, 96.3 (C-4), 157.7 (C-4a), 78.1 (C-6), 42.2 (C-6a), 34.1 (C-7), 104.6 (C7a), 160.0 (C-8), 94.5 (C-9), 159.5 (C-10), 97.9 (C-11), 155.2 (C-11a), 63.6 (C-12a), 103.5 (C-12b), $140.3\left(\mathrm{C}-1^{\prime}\right), 128.5\left(\mathrm{C}-2^{\prime}, 6^{\prime}\right), 129.6\left(\mathrm{C}-3^{\prime}\right.$, 
$\left.4^{\prime}, 5^{\prime}\right), 130.4(\mathrm{C}-\alpha), 131.9(\mathrm{C}-\beta), 130.2\left(\mathrm{C}-1^{\prime \prime}\right), 128.4\left(\mathrm{C}-2^{\prime \prime}, 6^{\prime \prime}\right), 116.2(\mathrm{C}-$ $\left.3^{\prime \prime}, 5^{\prime \prime}\right), 157.8\left(\mathrm{C}-4^{\prime \prime}\right), 56.4$ (1-OMe), 56.3 (8-OMe), 10-GlcA: 102.4 (C1'), 74.6 (C-2'), $77.4\left(\mathrm{C}-3^{\prime}\right), 73.1\left(\mathrm{C}-4^{\prime}\right), 76.5\left(\mathrm{C}-5^{\prime}\right), 172.7\left(\mathrm{C}-6^{\prime}\right)$; ESIMS/MS (PI): $m / z 701[\mathrm{M}+\mathrm{H}]^{+}, 447,271$; HRMS (NI): $m / z$ $699.2069[\mathrm{M}-\mathrm{H}]^{-}$(calcd for $\left.\mathrm{C}_{38} \mathrm{H}_{35} \mathrm{O}_{13}, 699.2078, \Delta=-1.3 \mathrm{ppm}\right)$.

4.6.3.7. Brachydin I (9). Amorphous white solid; $[\alpha]_{\mathrm{D}}^{21}-9,0^{\circ}$ (c 0.1 $\mathrm{MeOH}) ; \mathrm{UV} \lambda_{\max }(\log \varepsilon) 267 \mathrm{~nm}$ (5.67); ECD (MeOH, c $0.1 \mathrm{mM}$, $0.1 \mathrm{~cm})[\theta]_{215}=-97442,[\theta]_{225}=-42720 ;{ }^{1} \mathrm{H}$ NMR (DMSO-d6, $500 \mathrm{MHz}) \delta 6.30(1 \mathrm{H}, \mathrm{d}, J=2.0 \mathrm{~Hz}, \mathrm{H}-2), 6.20(1 \mathrm{H}, \mathrm{d}, J=2.0 \mathrm{~Hz}, \mathrm{H}-4)$, $4.76(1 \mathrm{H}, \mathrm{d}, J=11.1 \mathrm{~Hz}, \mathrm{H}-6), 2.55(1 \mathrm{H}, \mathrm{dd}, J=11.3,4.7 \mathrm{~Hz}, \mathrm{H}-6 \mathrm{a})$, $3.16(1 \mathrm{H}, \mathrm{m}, \mathrm{H}-7), 6.25(1 \mathrm{H}, \mathrm{d}, J=2.1 \mathrm{~Hz}, \mathrm{H}-9), 6.19(1 \mathrm{H}, \mathrm{d}, J=2.1 \mathrm{~Hz}$, H-11), 5.23 (1H, brs, H-12a), 7.33 (2H, m, H-2', 6'), 7.42 (3H, m, H-3', $\left.4^{\prime}, 5^{\prime}\right), 6.17(1 \mathrm{H}, \mathrm{dd}, J=15.1,4.7 \mathrm{~Hz}, \mathrm{H}-\alpha), 5.80(1 \mathrm{H}, \mathrm{d}, J=15.1 \mathrm{~Hz}, \mathrm{H}-$ $\beta), 7.26\left(2 \mathrm{H}, \mathrm{d}, J=8.7 \mathrm{~Hz}, \mathrm{H}-2^{\prime \prime}, 6^{\prime \prime}\right), 6.80\left(2 \mathrm{H}, \mathrm{d}, J=8.7 \mathrm{~Hz}, \mathrm{H}-3^{\prime \prime}, 5^{\prime \prime}\right)$, 3.79 (3H, s, 1-OMe), 3.60 (3H, s, 8-OMe), 3.71 (3H, s, 4"-OMe) 10GlcA: $4.98\left(1 \mathrm{H}, \mathrm{d}, J=7.1 \mathrm{~Hz}, \mathrm{H}-1^{\prime}\right), 3.22\left(1 \mathrm{H}, \mathrm{m}, \mathrm{H}-2^{\prime}\right), 3.27(1 \mathrm{H}$, $\left.\mathrm{m}, \mathrm{H}-3^{\prime}\right), 3.29\left(1 \mathrm{H}, \mathrm{m}, \mathrm{H}-4^{\prime}\right), 3.73\left(1 \mathrm{H}, \mathrm{m}, \mathrm{H}-5^{\prime}\right) ;{ }^{13} \mathrm{C}$ NMR (DMSO-d6, $126 \mathrm{MHz}$ ) $\delta 159.7$ (C-1), 94.1 (C-2), 160.1 (C-3), 96.7 (C-4), 155.6 (C4a), 77.0 (C-6), 39.4 (C-6a), 33.0 (C-7), 102.7 (C-7a), 159.1 (C-8), 94.2 (C-9), 158.8 (C-10), 96.5 (C-11), 154.1 (C-11a), 62.3 (C-12a), 104.8 (C12b), 139.0 (C-1'), $128.4\left(\mathrm{C}-2^{\prime}, 6^{\prime}\right), 129.3\left(\mathrm{C}-3^{\prime}, 4^{\prime}, 5^{\prime}\right), 130.9(\mathrm{C}-\alpha)$, $130.2(\mathrm{C}-\beta), 130.1\left(\mathrm{C}-1^{\prime \prime}\right), 128.1\left(\mathrm{C}-2^{\prime \prime}, 6^{\prime \prime}\right), 114.6\left(\mathrm{C}-3^{\prime \prime}, 5^{\prime \prime}\right), 159.4(\mathrm{C}-$ $\left.4^{\prime \prime}\right), 56.4$ (1-OMe), 56.3 (8-OMe), 55.8 (4"-OMe), 10-GlcA: 100.6 (C$\left.1^{\prime}\right), 73.7$ (C-2'), 76.7 (C-3'), 72.2 (C-4'), 75.3 (C-5'); ESIMS/MS (PI): $m / z 737[\mathrm{M}+\mathrm{Na}]^{+}, 461,285$; $\operatorname{HRMS}(\mathrm{NI}): \mathrm{m} / z 713.2256\left[^{[\mathrm{M}-\mathrm{H}]^{-}}\right.$ (calcd for $\mathrm{C}_{39} \mathrm{H}_{37} \mathrm{O}_{13}, 713.2234, \Delta=3.1 \mathrm{ppm}$ ).

4.6.3.8. Brachydin $J$ (10). Amorphous white solid; $[\alpha]_{D}^{20}-6,4$ (c 0.1 $\mathrm{MeOH}) ; \mathrm{UV} \lambda_{\max }(\log \varepsilon) 266 \mathrm{~nm}$ (5.78); ECD (MeOH, c $0.1 \mathrm{mM}$, $0.1 \mathrm{~cm})[\theta]_{215}=-45694,[\theta]_{225}=-17236 ;{ }^{1} \mathrm{H}$ NMR $\left(\mathrm{CD}_{3} \mathrm{OD}\right.$, $500 \mathrm{MHz}) \delta 6.09(1 \mathrm{H}, \mathrm{d}, J=2.1 \mathrm{~Hz}, \mathrm{H}-2), 5.95(1 \mathrm{H}, \mathrm{d}, J=2.1 \mathrm{~Hz}, \mathrm{H}-4)$, $4.77(1 \mathrm{H}, \mathrm{d}, J=11.2 \mathrm{~Hz}, \mathrm{H}-6), 2.28(1 \mathrm{H}, \mathrm{dt}, J=11.2,2.1 \mathrm{~Hz}, \mathrm{H}-6 \mathrm{a}), 3.24$ $(1 \mathrm{H}, \mathrm{dt}, J=5.6,2.1 \mathrm{~Hz}, \mathrm{H}-7), 6.36(1 \mathrm{H}, \mathrm{d}, J=2.3 \mathrm{~Hz}, \mathrm{H}-9), 6.30(1 \mathrm{H}, \mathrm{d}$, $J=2.3 \mathrm{~Hz}, \mathrm{H}-11), 5.31(1 \mathrm{H}, \mathrm{d}, J=2.1 \mathrm{~Hz}, \mathrm{H}-12 \mathrm{a}), 7.23\left(2 \mathrm{H}, \mathrm{m}, \mathrm{H}-2^{\prime}\right.$, $\left.6^{\prime}\right), 7.38\left(3 \mathrm{H}, \mathrm{m}, \mathrm{H}-3^{\prime}, 4^{\prime}, 5^{\prime}\right), 6.17(1 \mathrm{H}, \mathrm{dd}, J=15.8,5.6 \mathrm{~Hz}, \mathrm{H}-\alpha), 5.89$ $(1 \mathrm{H}, \mathrm{dd}, J=15.8,2.1 \mathrm{~Hz}, \mathrm{H}-\beta), 7.19\left(4 \mathrm{H}, \mathrm{m}, \mathrm{H}-2^{\prime \prime}, 3^{\prime \prime}, 5^{\prime \prime}, 6^{\prime \prime}\right), 7.11(1 \mathrm{H}$, m, H-4"), 3.80 (3H, s, 1-OMe), 3.65 (3H, s, 8-OMe), 10-GlcA: 5.00 $\left(1 \mathrm{H}, \mathrm{d}, J=7.3 \mathrm{~Hz}, \mathrm{H}-1^{\prime}\right), 3.50\left(1 \mathrm{H}, \mathrm{m}, \mathrm{H}-2^{\prime}\right), 3.52\left(1 \mathrm{H}, \mathrm{m}, \mathrm{H}-3^{\prime}\right), 3.61$ $\left(1 \mathrm{H}, \mathrm{m}, \mathrm{H}-4^{\prime}\right), 4.00\left(1 \mathrm{H}, \mathrm{d}, J=9.7 \mathrm{~Hz}, \mathrm{H}-5^{\prime}\right) ;{ }^{13} \mathrm{C}$ NMR $\left(\mathrm{CD}_{3} \mathrm{OD}\right.$, $126 \mathrm{MHz}$ ) $\delta 161.1$ (C-1), 92.8 (C-2), 161.1 (C-3), 96.4 (C-4), 157.8 (C4a), 78.0 (C-6), 42.0 (C-6a), 34.2 (C-7), 104.4 (C-7a), 160.0 (C-8), 94.5 (C-9), 159.6 (C-10), 97.9 (C-11), 155.3 (C-11a), 63.7 (C-12a), 103.5 (C12b), $140.3\left(\mathrm{C}-1^{\prime}\right), 128.5\left(\mathrm{C}-2^{\prime}, 6^{\prime}\right), 129.5\left(\mathrm{C}-3^{\prime}, 5^{\prime}\right), 129.7\left(\mathrm{C}-4^{\prime}\right), 133.3$

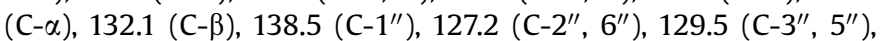
128.2 (C-4" ), 56.0 (1-OMe), 56.1 (8-OMe), 10-GlcA: 102.3 (C-1'), 74.5 (C-2'), $77.4\left(\mathrm{C}-3^{\prime}\right), 73.0\left(\mathrm{C}-4^{\prime}\right), 76.5\left(\mathrm{C}-5^{\prime}\right), 172.7\left(\mathrm{C}-6^{\prime}\right)$; ESIMS/MS (PI): $m / z 707[\mathrm{M}+\mathrm{Na}]^{+}, 685,255$; HRMS (NI): $m / z 683.2158[\mathrm{M}-\mathrm{H}]^{-}$ (calcd for $\mathrm{C}_{38} \mathrm{H}_{35} \mathrm{O}_{12}, 683.2129, \Delta=4.2 \mathrm{ppm}$ ).

\subsection{HPLC-PDA-MS analysis}

HPLC-PDA-MS data were obtained with an Agilent HP 1100 series system consisting of an autosampler, high-pressure mixing pump and PDA detector (Agilent Technologies, Santa Clara, CA, USA) connected to a Finnigan MAT LCQ ion trap mass spectrometer (Finnigan, San Jose, CA, USA) equipped with a Finnigan electrospray interface (ESI). The HPLC conditions were as follows: XBridge C-18 column ( $5 \mu \mathrm{m}, 250 \times 4.6 \mathrm{~mm}$ i.d.) (Waters, Middleton, WI, USA); solvent system: $\mathrm{A}, \mathrm{MeOH}$ containing $0.002 \%$ formic acid and $\mathrm{B}, \mathrm{H} 2 \mathrm{O}$ containing $0.002 \%$ formic acid; gradient: $5-100 \%$ of $A$ in 60 min followed by $100 \%$ of $A$ for $10 \mathrm{~min}$; flow rate: $1 \mathrm{ml} / \mathrm{min}$; injection volume: $10 \mu \mathrm{l}$; and sample concentration: $10 \mathrm{mg} / \mathrm{ml}$ in $\mathrm{MeOH}$. The UV absorbance was measured at 210 and $254 \mathrm{~nm}$, and UV spectra (PDA) were recorded between 190 and $600 \mathrm{~nm}$ (in increments of
$2 \mathrm{~nm})$. ESI-MS conditions were as follows: capillary voltage: $30 \mathrm{~V}$; capillary temperature: $200{ }^{\circ} \mathrm{C}$; source voltage: $4.5 \mathrm{kV}$; source current: $801 \mathrm{~A}$; nitrogen as the sheath gas; and positive and negative ion mode. Spectra (180-1200 mu) were recorded every $3 \mathrm{~s}$.

\subsection{HPLC-PDA-MS/MS analysis}

The mass spectrometry experiments were performed on LCQ Fleet equipment (Thermo Scientific, ${ }^{*}$ ) equipped with a dispositive of direct insertion of the sample via flow injection analysis (FIA). The studied matrix was analysed by electrospray ionization (ESI), and fragmentation in multiple stages $\left(\mathrm{MS}^{2}, \mathrm{MS}^{3}\right.$ and $\mathrm{MS}^{\mathrm{n}}$ ) was performed at an ion trap (IT) interface. The positive mode was selected for the generation and analysis of the mass spectra for the first order (MS) and for the remaining multistage experiments under the following conditions: capillary voltage, $-25 \mathrm{~V}$; voltage spray, $-5 \mathrm{kV}$; and capillary temperature, $275^{\circ} \mathrm{C}$. A carrier gas $\left(\mathrm{N}_{2}\right)$ with a flow of 8 arbitrary units (A.U.) was used, and the collision gas was helium (He). The track acquisition was $m / z$ 100-2000. Xcalibur version 1.3 software (Thermo Finnigan, Waltham, MA) was used to acquire and process the data.

\section{Acknowledgments}

The authors thank the São Paulo State Research Foundation (FAPESP) for funding and fellowships (grant 2009/52237-9 to W.V., grant 2014/03728-8 to C.Q.R. and grant 2012/01868-1 to A.F.G.). The authors also thank Prof. Maria Cristina Teixeira Braga Messias, from the José Badine Herbarium of Federal University of Ouro Preto, Brazil for assistance with botanical identification and Mauricio Mercadante for the photography of $A$. brachypoda presented in the graphical abstract.

\section{Appendix A. Supplementary data}

Supplementary data related to this article can be found at http:// dx.doi.org/10.1016/j.phytochem.2016.12.002.

\section{References}

Arakawa, T., Watanabe, T., Tanigawa, T., Tominaga, K., Fujiwara, Y., Morimoto, K. 2012. Quality of ulcer healing in gastrointestinal tract: its pathophysiology and clinical relevance. World J. Gastroenterol. 18, 4811-4822.

Betton, G.R., 2013. A review of the toxicology and pathology of the gastrointestinal tract. Cell Biol. Toxicol. 29, 321-338.

Bruhn, T.S.A., Hemberger, Y., Bringmann, G., 2013. SpecDis Version 1.61. University of Wuerzburg, Germany.

Challal, S., Queiroz, E.F., Debrus, B., Kloeti, W., Guillarme, D., Gupta, M.P. Wolfender, J.L., 2015. Rational and efficient preparative isolation of natural products by MPLC-UV-ELSD based on HPLC to MPLC gradient transfer. Planta Med. 81, 1636-1643.

Corne, S.J., Morrissey, S.M., Woods, R.J., 1974. Proceedings: a method for the quantitative estimation of gastric barrier mucus. J. Physiol. 242, 116P-117P.

da Rocha, C.Q., Queiroz, E.F., Meira, C.S., Moreira, D.R.M., Soares, M.B.P., Marcourt, L. Vilegas, W., Wolfender, J.L., 2014. Dimeric flavonoids from Arrabidaea brachypoda and assessment of their anti -Trypanosoma cruzi activity. J. Nat. Prod. 77, 1345-1350.

da Rocha, C.Q., Vilela, F.C., Cavalcante, G.P., Santa-Cecilia, F.V., Santos-e-Silva, L., dos Santos, M.H., Giusti-Paiva, A., 2011. Anti-inflammatory and antinociceptive effects of Arrabidaea brachypoda (DC.) Bureau roots. J. Ethnopharmacol. 133, 396-401.

de-Faria, F.M., Almeida, A.C., Luiz-Ferreira, A., Dunder, R.J., Takayama, C., da Silva, M.S., da Silva, M.A., Vilegas, W., Rozza, A.L., Pellizzon, C.H., Toma, W., Souza-Brito, A.R., 2012a. Mechanisms of action underlying the gastric antiulcer activity of the Rhizophora mangle L. J. Ethnopharmacol. 139, 234-243.

de-Faria, F.M., Almeida, A.C., Luiz-Ferreira, A., Takayama, C., Dunder, R.J., da Silva, M.A., Salvador, M.J., Abdelnur, P.V., Eberlin, M.N., Vilegas, W., Toma, W., Souza-Brito, A.R., 2012b. Antioxidant action of mangrove polyphenols against gastric damage induced by absolute ethanol and ischemia-reperfusion in the rat. Sci. World J. 2012, 327071.

Dennis, E.A., Norris, P.C., 2015. Eicosanoid storm in infection and inflammation. Nat. Rev. Immunol. 15, 511-523. 
Domon, B., Costello, C.E., 1988. A systematic nomenclature for carbohydrate frag mentations in fab-ms ms spectra of glycoconjugates. Glycoconj. J. 5, 397-409.

Farzaei, M.H., Abdollahi, M., Rahimi, R., 2015. Role of dietary polyphenols in the management of peptic ulcer. World J. Gastroenterol. 21, 6499-6517.

Frisch, M.J., Trucks, G.W.S.H.B., Scuseria, G.E., Robb, M.A., Cheeseman, J.R., Scalmani, G., Barone, V., Mennucci, B., Petersson, G.A., Nakatsuji, H., Caricato, M., Li, X., Hratchian, H.P., Izmaylov, A.F., Bloino, J., Zheng, G., Sonnenberg, J.L. Hada, M., Ehara, M., Toyota, K., Fukuda, R., Hasegawa, J., Ishida, M., Nakajima, T., Honda, Y., Kitao, O., Nakai, H., Vreven, T., Montgomery, J.A., Peralta, J.E., Ogliaro, F., Bearpark, M., Heyd, J.J., Brothers, E., Kudin, K.N., Staroverov, V.N., Kobayashi, R., Normand, J., Raghavachari, K., Rendell, A., Burant, J.C. Iyengar, S.S., Tomasi, J., Cossi, M., Rega, N., Millam, J.M., Klene, M., Knox, J.E. Cross, J.B., Bakken, V., Adamo, C. Jaramillo, J. Gomperts, R. Stratmann, R.E. Yazyev, O., Austin, A.J., Cammi, R., Pomelli, C., Ochterski, J.W., Martin, R.L. Morokuma, K., Zakrzewski, V.G., Voth, G.A., Salvador, P., Dannenberg, J.J., Dapprich, S., Daniels, A.D., Farkas, O., Foresman, J.B., Ortiz, J.V., Cioslowski, J., Fox, D.J., 2009. Gaussian 09, Revision A02. Gaussian, Inc, Wallingford CT.

Gonzalez, B., Suarez-Roca, H., Bravo, A., Salas-Auvert, R., Avila, D., 2000. Chemica composition and biological activity of extracts from Arrabidaea bilabiata. Pharm. Biol. 38, 287-290.

Kangwan, N., Park, J.M., Kim, E.H., Hahm, K.B., 2014. Quality of healing of gastric ulcers: natural products beyond acid suppression. World J. Gastrointest. Pathophysiol. 5, 40-47.

Kauffman Jr., G.L., 1981. Gastric mucus and bicarbonate secretion in relation to mucosal protection. J. Clin. Gastroenterol. 3, 45-50.

Kobayashi, S., Nakajima, N., Ito, Y., Moriyama, M., 2010. Effects of lansoprazole on the expression of VEGF and cellular proliferation in a rat model of acetic acidinduced gastric ulcer. J. Gastroenterol. 45, 846-858.

Krawisz, J.E., Sharon, P., Stenson, W.F., 1984. Quantitative assay for acute intestinal inflammation based on myeloperoxidase activity. Assessment of inflammation in rat and hamster models. Gastroenterology 87, 1344-1350.

Kwiecien, S., Magierowska, K., Sliwowski, Z., Wojcik, D., Magierowski, M. Brzozowski, T., 2015. New insight into the mechanisms of gastroduodena injury induced by nonsteroidal anti-inflammatory drugs: practical implications. Pol. Arch. Med. Wewn. 125, 191-198.

Laine, L., Takeuchi, K., Tarnawski, A., 2008. Gastric mucosal defense and cytoprotection: bench to bedside. Gastroenterology 135, 41-60.

Leite, J.P., Oliveira, A.B., Lombardi, J.A., Filho, J.D., Chiari, E., 2006. Trypanocidal activity of triterpenes from Arrabidaea triplinervia and derivatives. Biol. Pharm. Bull. 29, 2307-2309.

Lohmann, L.G., 2006. Untangling the phylogeny of neotropical lianas (Bignonieae Bignoniaceae). Am. J. Bot. 93, 304-318.

Malfertheiner, P., Chan, F.K., McColl, K.E., 2009. Peptic ulcer disease. Lancet 374 1449-1461.

Martin, F., Hay, A.E., Cressend, D., Reist, M., Vivas, L., Gupta, M.P., Carrupt, P.A Hostettmann, K., 2008. Antioxidant C-glucosylxanthones from the leaves of Arrabidaea patellifera. J. Nat. Prod. 71, 1887-1890.

Matsuda, H., Li, Y., Yoshikawa, M., 1999. Roles of capsaicin-sensitive sensory nerves, endogenous nitric oxide, sulfhydryls, and prostaglandins in gastroprotection by momordin Ic, an oleanolic acid oligoglycoside, on ethanol-induced gastric mucosal lesions in rats. Life Sci. 65, PL27-32.

Okabe, S., Amagase, K., 2005. An overview of acetic acid ulcer models-the history and state of the art of peptic ulcer research. Biol. Pharm. Bull. 28, 1321-1341.

Okabe, S., Roth, J.L., Pfeiffer, C.J., 1971. A method for experimental, penetrating gastric and duodenal ulcers in rats. Observations on normal healing. Am. J. Dig. Dis. 16, 277-284.

Olfert, E.D., Cross, B.M., McWilliam, A.A., 1993. Guide to the Care and Use of Experimental Animals. Canadian Council on Animal Care Co, Ontario.

Pauletti, P.M., Bolzani, V.D., Young, M.C.M., 2003. Chemical constituents of Arrabidaea samydoides (Bignoniaceae). Quim. Nova 26, 641-643.

Peskar, B.M., 1980. Effect of carbenoxolone on prostaglandin synthesizing and metabolizing enzymes and correlation with gastric mucosal carbenoxolone concentrations. Scand. J. Gastroenterol. Suppl. (Suppl. 65), 109-114.

Quan, C., Talley, N.J., 2002. Management of peptic ulcer disease not related to Helicobacter pylori or NSAIDs. Am. J. Gastroenterol. 97, 2950-2961.

Rahim, N.A., Hassandarvish, P., Golbabapour, S., Ismail, S., Tayyab, S., Abdulla, M.A. 2014. Gastroprotective effect of ethanolic extract of Curcuma xanthorrhiza leaf against ethanol-induced gastric mucosal lesions in sprague-dawley rats. Biomed. Res. Int. 2014, 416409.

Robert, A., Nezamis, J.E., Lancaster, C., Hanchar, A.J., 1979. Cytoprotection by prostaglandins in rats. Prevention of gastric necrosis produced by alcohol, $\mathrm{HCl}$ $\mathrm{NaOH}$, hypertonic $\mathrm{NaCl}$, and thermal injury. Gastroenterology 77, 433-443.

Shaw, S., Herbert, V., Colman, N., Jayatilleke, E., 1990. Effect of ethanol-generated free radicals on gastric intrinsic factor and glutathione. Alcohol 7, 153-157.

Shay, H., Komarov, S.A., Fels, S.S., Meranze, D., Gruestein, M., Siplet, H., 1945. A simple method for the uniform production of gastric ulceration in the rat. Gastroenterology 5, 41-61.

Souza-Brito, A.R.M., 1994. Manual de ensaios tecnológicos in vivo. Editora da UNICAMP, Campinas, São Paulo, Brasil.

Szabo, S., 2014. "Gastric cytoprotection" is still relevant. J. Gastroenterol. Hepatol. 29 (Suppl. 4), 124-132.

Szabo, S., Nagy, L., Plebani, M., 1992. Glutathione, protein sulfhydryls and cysteine proteases in gastric mucosal injury and protection. Clin. Chim. Acta 206, 95-105.

Takeuchi, K., 2012. Pathogenesis of NSAID-induced gastric damage: importance of cyclooxygenase inhibition and gastric hypermotility. World J. Gastroenterol. 18, 2147-2160.

Tarnawski, A., Hollander, D., Krause, WJ. Dabros, W. Stachura, J., Gergely, H., 1990 "Healed" experimental gastric ulcers remain histologically and ultrastructurally abnormal. J. Clin. Gastroenterol. 12 (Suppl. 1), 139-147.

Tsuji, S., Sun, W.H. Tsujii, M., Kawai, N., Kimura, A., Kakiuchi, Y, Yasumaru, S., Komori, M., Murata, H. Sasaki, Y., Kawano, S., Hori, M., 2002. Lansoprazole induces mucosal protection through gastrin receptor-dependent up-regulation of cyclooxygenase-2 in rats. J. Pharmacol. Exp. Ther. 303, 1301-1308.

Vane, J.R., Bakhle, Y.S., Botting, R.M., 1998. Cyclooxygenases 1 and 2. Annu. Rev. Pharmacol. Toxicol. 38, 97-120.

Wallace, J.L., Devchand, P.R., 2005. Emerging roles for cyclooxygenase-2 in gastrointestinal mucosal defense. Br. J. Pharmacol. 145, 275-282.

Wallace, J.L., McKnight, W., Reuter, B.K., Vergnolle, N., 2000. NSAID-induced gastric damage in rats: requirement for inhibition of both cyclooxygenase 1 and 2 . Gastroenterology 119, 706-714.

Whittle, B.R., 1975. Proceedings: gastric acidity and the mechanisms by which prostaglandins prevent indomethacin-induced gastric erosions. Br. J. Pharmacol. 55, 242-243.

Yuan, Y., Padol, I.T., Hunt, R.H., 2006. Peptic ulcer disease today. Nat. Clin. Pract. Clin. Gastroenterol. Hepatol. 3, 80-89.

Zhong, X.N., Otsuka, H., Ide, T., Hirata, E., Takeda, Y., 1999. Hydroquinone diglycoside acyl esters from the leaves of Myrsine seguinii. Phytochemistry 52, 923-927. 